\title{
On the (Ir)Relevance of Monetary Aggregate Targeting in Pakistan: An Eclectic View
}

\author{
Adnan Haider, ${ }^{*}$ Asad Jan, ${ }^{* *}$ and Kalim Hyder ${ }^{* * *}$
}

\begin{abstract}
This study attempts to identify a stable money demand function for Pakistan's economy, where the monetary aggregate is considered the nominal anchor. With evolving financial innovations and regulations, the stability of money demand has been the focus of numerous debates. Where earlier studies have provided conflicting explanations due to inadequate specifications and imprecise estimations, we find that money demand in Pakistan is stable, if specified properly. For developing countries such as Pakistan, it is important to target monetary aggregates or respond to deviations from the desirable path if monetary policy is to be effectively implemented and communicated; this should remain, if not a primary, then an auxiliary target in the monetary policy framework.
\end{abstract}

Keywords: money demand, stability, monetarism.

JEL classification: C20, E12, E41, E5.

\section{Introduction}

The role of monetary aggregate(s) as a virtue has long been debated in the conduct of monetary policy. It is generally believed that money carries important information about the underlying state of an economy and can help predict discernible monetary facts. Although most central banks have used monetary aggregates as an intermediate target in their monetary policy frameworks, the usefulness of monetary aggregates has diminished, particularly since the early 1990s when the money demand function became subject to structural changes (see, for instance, Mishkin, 2000; Woodford, 1998, 2008).

It is generally argued that successful monetary aggregate targeting requires a stable, or at least predictable, relationship between

\footnotetext{
* Assistant Professor, Department of Economics and Finance, Institute of Business Administration (IBA), Karachi, Pakistan.

** Economic Analyst, Monetary Policy Department, State Bank of Pakistan.

**** PhD Fellow, Department of Economics, University of Leicester, UK.
} 
money growth and inflation. However, this relationship has become more obscure, particularly in advanced economies, since the 1990s with the evolution of the financial sector. ${ }^{1}$ Financial deregulation and innovation have significantly changed the preferences of households and the financial sector and thus destabilized the money demand function (Arrau, De Gregorio, Reinhart, \& Wickham, 1995; Bernanke, 2006). ${ }^{2}$ As a consequence, many developed and developing countries have changed their nominal anchor and switched from a monetary aggregate targeting regime to inflation targeting or price level targeting.

Nevertheless, monetary aggregates contain important information and their significance in monetary policy frameworks cannot be ignored. A detailed assessment of monetary trends and their relationships with goal variables (output growth and inflation) can provide useful information on the demand pressures in an economy-this, in turn, drives our analysis of the specification and stability of the money demand function in Pakistan.

The core functional specification of money demand is derived from a set of intertemporal optimal decisions made by households and firms in a dynamic stochastic general equilibrium (DSGE) setting. This specification is then estimated empirically using various econometric techniques while investigating other potential determinants of money demand in terms of their goodness of fit. This is because the preferences of households and firms have, to some extent, changed and the operational scope of the financial sector widened over the last two decades (see State Bank of Pakistan, n.d.). However, the development of structured financial instruments is still in an evolutionary phase, making it necessary to analyze different empirical specifications for a robustness check.

Another important empirical contribution of this paper is that it provides an eclectic stability analysis both in terms of models and parameters. Although numerous empirical estimations of the money demand function have focused on the stability of money demand and the velocity of money in the context of Pakistan, the results are mixed. ${ }^{3}$ Some studies find a robust relationship between money and the goal variables (see Qayyum, 2005; Omer, 2010; Azim, Ahmed, Ullah, Zaman, \& Zakaria, 2010) while other find an unstable money demand function (see

\footnotetext{
${ }^{1}$ When households started to invest in bonds and mutual funds.

${ }^{2}$ Lieberman (1977) argues that the "increased use of credit, better synchronization of receipts and expenditures, reduced mail float, more intensive use of money substitutes, and more efficient payments mechanisms will tend to permanently decrease the transaction demand for money over time."

${ }^{3}$ A quick review of earlier empirical studies on the money demand function in Pakistan is given in Appendix I.
} 
Moinuddin, 2009; Omer \& Saqib, 2009). It is interesting to note that, even when using almost the same specification and methodology but a different sample range, researchers have arrived at conflicting results. ${ }^{4}$ In addition, while earlier studies talk about model stability, they do not evaluate the parameter stability of money demand. Among other variables, the consistency of interest rate sensitivity is important for the stability of money demand: changing interest rate sensitivity over time would mean that a money demand estimate in one period may not be able to predict money demand as well in other period (Mishkin, 1995).

There are a number of ways to empirically determine the stability of money demand. Earlier studies show that the mere existence of a longrun relationship between monetary aggregates and their determinants is a sign of stable money demand. However, this argument does not qualify for stability and requires more statistical tests to determine whether both longrun and short-run elasticities remain stable over time (Bahmani-Oskooee \& Rehman, 2010). These tests include the recursive estimation of coefficients and analysis of evolution. If the coefficients vary significantly-both in magnitude and sign - as more information is added to a sample, then this would indicate instability.

The problem of instability may not necessarily be due to the incorrect specification of a long-run function but due to the inadequate modeling of short-term dynamics (see, for example, Laidler, 1993). Therefore, it is important that the money demand function should be correctly specified both in the long term and in the short term.

Another way to determine money demand stability is to analyze the velocity of monetary aggregates. Omer and Saqib (2009) model the velocity of money (M0, M1, M2) in a univariate fashion and argue that each series of monetary aggregates is not mean-reverting and is integrated of high order, i.e., I(1). They conclude that the velocities are nonstationary at level, which signifies instability in money demand. However, this analysis does not qualify as determining money demand stability because most economic time-series depicting a trend (and thus nonstationarity) can be explained by structural changes ${ }^{5}$ an empirical point highlighted by

\footnotetext{
${ }^{4}$ Qayyum (2005) and Moinuddin (2009) use real M2, real GDP, and the call money rate for the period 1960-99 and 1974-06, respectively.

${ }^{5}$ During the last two decades, Pakistan's economy, particularly its financial sector, has undergone structural changes that include the opening of the equity market and long-term and short-term bond market for government securities, the introduction of foreign currency accounts, the liberalization (to some extent) of external accounts, and opening of new domestic and foreign private banks.
} 
Ericsson, Hendry, and Prestwich (1997). Therefore, if an empirical specification were modeled properly, the result could be different.

Section 2 gives some stylized facts about monetary aggregates in Pakistan during 1992-2011. Section 3 describes our empirical methodology in detail. Section 4 discusses the empirical estimation, stability issues, and results of the money demand function, and Section 5 concludes the study.

\section{Some Stylized Monetary Facts in Pakistan}

Before investigating model specifications and technical details, it is important to visualize the various temporal developments of selected macro/monetary economic indicators in Pakistan. Figures 1-6 show the trends in broad money (M2) and the consumer price index (CPI); the variables are mean-adjusted and in log form in order to bring in one scale. Over the last two decades, nominal money has increased around fourteenfold while consumer prices have risen four times from the level of FY1991, which witnessed a significant increase in M2. 
Figure 1-6: Developments in monetary aggregates in Pakistan

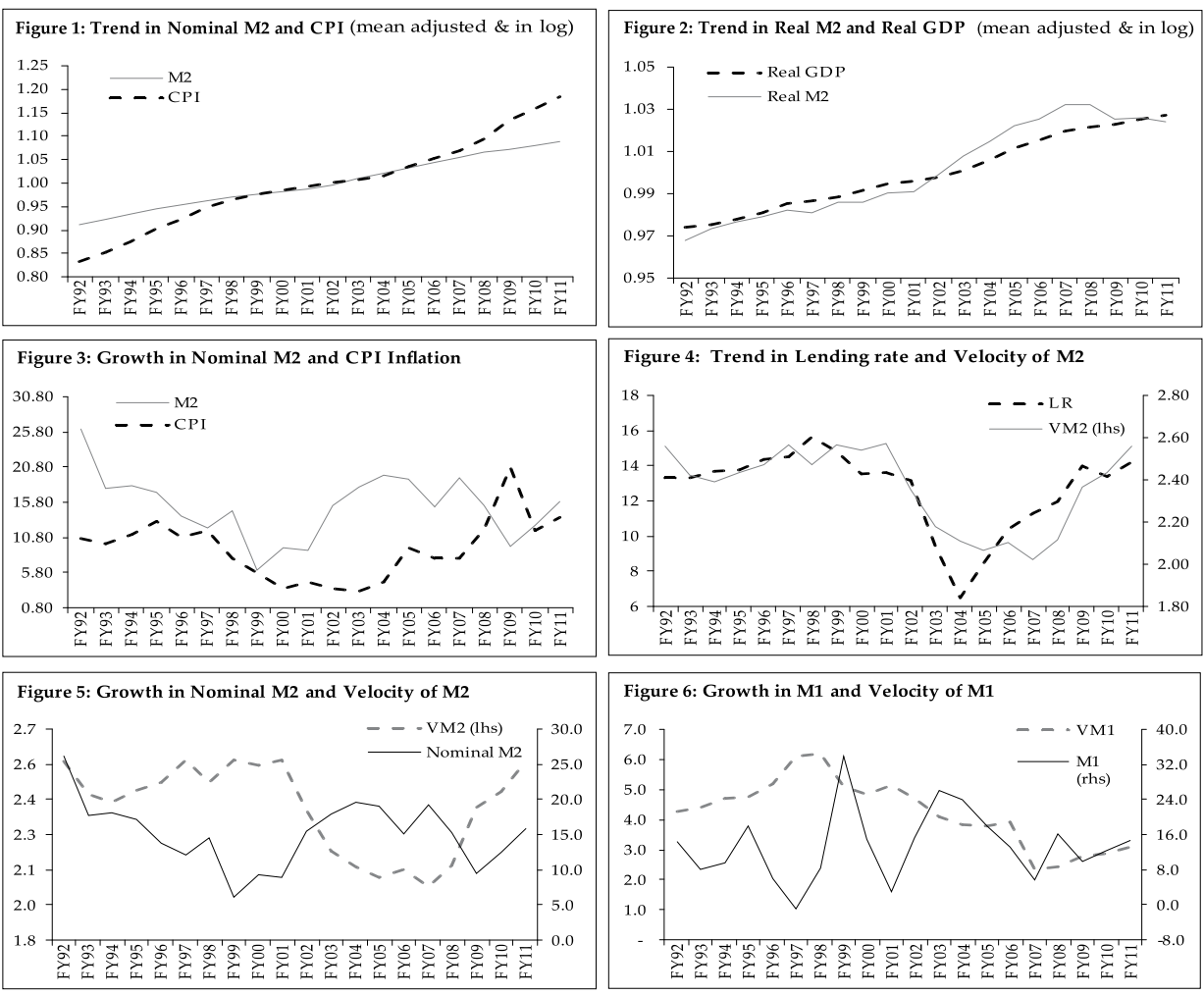

In Figure 2, real money increases parallel to real GDP, gaining pace in 2001 and onward mainly due to a significant increase in foreign inflows (although sterilized by some inflows from the central bank through FY2004) and subdued inflation. This phenomenal increase in nominal and real money has had serious repercussions for the economy in terms of high inflation and protracted low economic growth.

Figure 3 shows that consumer price inflation stabilized once monetary growth was controlled (particularly in 1995, when money targeting was institutionalized). However, the significant growth in nominal money in the early 2000s induced inflationary pressure in the subsequent period. During the last decade, nominal money increased by 15.2 percent per annum on average while CPI inflation increased to 8.4 percent per annum on average. This inflationary pressure was more pronounced after FY2008 due to frequent government borrowing from the State Bank of Pakistan (SBP) for budgetary support (inflationary in nature) coupled with an exorbitant rise in international commodity pricesparticularly energy prices-in FY2008 and the erosion of domestic currency. 
Money velocity (VM2) fell moderately from 2.6 in FY2001 to around 2.0 in FY2007 and the interest rate almost touched bottom in FY2004 (Figure 4). Interestingly, the velocity of narrow money shows more volatility than that of broad money due to the impulsive nature of demand deposits (DD) and currency in circulation (CIC) (Figures 5 and 6).

Figure 7: Components of broad money
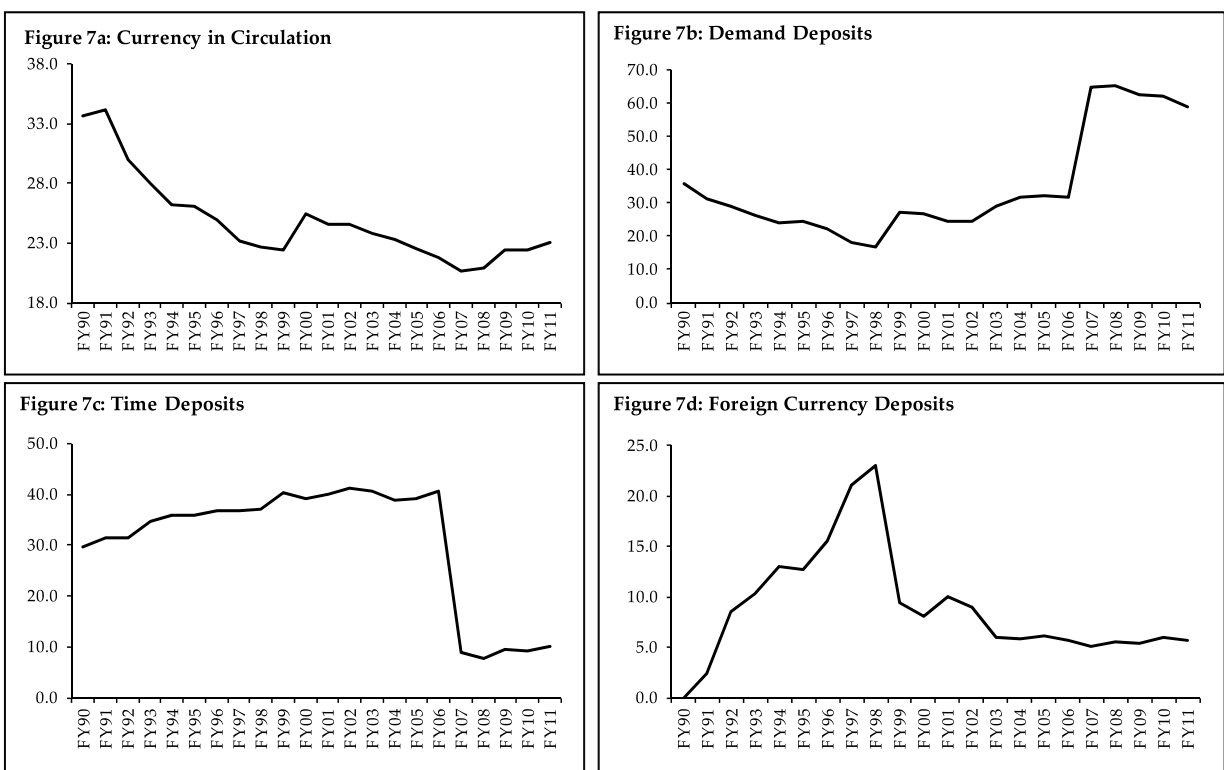

In Pakistan, broad money (M2) includes CIC, deposits with the SBP, demand and time deposits, and foreign currency deposits. Figure 7 shows the contribution of the four major components of broad money, where the share of CIC declines from a little over 34 percent in 1991 to 22 percent in 2010. The contribution of DD to broad money also declines during the 1990s, but bottoms out in 1998 after the freezing of resident foreign currency deposit (RFCD) accounts.

The earlier decline in CIC and DD was primarily due to the introduction of RFCDs in 1991; their share in broad money increased to 23 percent in 1998. However, subsequent to Pakistan's nuclear tests, foreign currency accounts were frozen for fear of foreign sanctions and capital flight. On the other hand, time deposits are seen to increase moderately over time. The data indicate a clear shift from time deposits to DD in 2007 due to a change in classification: deposits with a six-month to one-year tenure (previously time deposits) are now reported as DD. Together, demand and time deposits constitute around 75 percent of broad money. 


\section{Empirical Methodology}

The standard money demand function in linear form is written as: ${ }^{6}$

$$
\overline{\left(\frac{M_{t}}{P_{t}}\right)}=\varphi_{0}+\varphi_{1}\left(\widetilde{Y_{t}}\right)+\varphi_{2}\left(\tilde{l}_{t}\right)+\tilde{\varepsilon}_{m, t}
$$

Where $\varphi_{1}$ and $\varphi_{2}$ are the output and interest elasticities of money demand, respectively. From a theoretical perspective, the money demand function is positively related to output and negatively to the nominal interest rate.

This specification of money demand is consistent with the basic version of Friedman's money demand function. However, Friedman and his followers also consider other potential determinants of money demand: $M_{d} / P=f\left(W, r-r^{e}, \pi^{e}, h\right)$, where $M_{d} / P$ denotes real money balances, $W$ is wealth, $r$ is the interest rate, $\mathrm{r}^{\mathrm{e}}$ is the expected change in the interest rate, is the expected change in price level, and $h$ is the ratio of human to nonhuman wealth. In practice, however, it is difficult to determine the volume of wealth in the economy and, therefore, a scale variable (usually real GDP or, in some instances, real consumption) is used as a proxy as we also observe in the final specification of the above micro-founded model.

There is widespread agreement in the empirical literature on the choice of scale variable although various theories of money demand have highlighted the importance of different scale variables. For instance, transaction-related theories suggest real income while portfolio approaches emphasize financial wealth (Calza, Gerdesmeier, \& Levy, 2001). Regarding empirical estimates of income elasticity (i.e., the responsiveness of the demand for money to changes in real income), the quantity theory suggests a one-to-one relationship between real balances (M2) and real income while the Baumol-Tobin model of the transaction demand for money specifies 0.5 (Calza et al., 2001). However, in developing countries, income elasticity is much higher (more than 1 percent) mainly due to insufficient avenues for alternative financial assets and the pervasive monetization of the economy (Adam, Kessy, Nyella, \& O'Connell, 2010). Some empirical studies use stock prices or volatility as an additional variable in the money demand function to substantiate the wealth effect (Bruggeman, Donati, \& Warne, 2003).

Economic theory also considers the interest rate an important variable that reflects the opportunity cost of holding money, but it provides

\footnotetext{
${ }^{6}$ Appendix A deals with the derivation and analytical foundations of the money demand function outlined here.
} 
little guidance on selecting an appropriate interest rate (Laidler, 1993). The empirical literature uses a variety of interest rates, including the short-term market or bond rate, the long-term rate, and the rate of return on alternative financial assets. In portfolio decision-making, economic agents treat a variety of assets as alternatives to money, and therefore a wide spectrum of rates of return should be included in the money demand function (Heller \& Khan, 1979). However, this raises some statistical issues (i.e., most interest rates are co-linear) and complicates the estimation of the model. Since most interest rates move in more or less the same direction, researchers are best restricted to limited rates of return (Calza et al., 2001).

In the case of developing countries, where the financial market (particularly the long-term bond and equity markets) is not fully developed, the money demand function should include the short-term market interest rate. Further, economic agents may choose short-term financial assets as an alternative to money in high inflationary environments while opting for long-term assets when economic conditions are stable and predictable.

Since a significant portion of monetary aggregates (M2 or M3) is remunerative (including demand and time deposits, foreign currency deposits, and various saving schemes), the own rate of return on monetary aggregates cannot be ignored. Bruggeman et al. (2003) use the weighted average rate of return on different components of $\mathrm{M} 2 / \mathrm{M} 3$ to calculate the own rate for each country in the euro area. It is generally expected that the coefficient of the own rate of interest will have a nonnegative value, i.e., an increase in the own rate will raise the demand for real balances (Laidler, 1993). However, a tight monetary stance may raise the own rate of interest, which, in turn, increases the demand for money. This seems contradictory to the essence of monetary policy (Calza et al. 2001) and, therefore, most studies use interest rate spreads (the market rate minus the own rate or the bond rate minus the own rate) instead of just the own rate.

The expected change in price level enters a money demand function as the opportunity cost of holding money along with the nominal interest rate. Importantly, the change in price level affects the rate of return on the inventory of goods as high expected inflation induces economic agents to shift from money to goods, i.e., to stocking inventory, due to high profit incentives. However, Golineli and Pastorello (2002) do not include inflation as a measure of the opportunity cost of holding money in their long-run specification of the money demand function, arguing that it has no additional explanatory content compared to the long-term interest rate. 
Other money demand specifications include the exchange rate (or depreciation) in order to capture the effect of currency substitution. Exchange rate depreciation can have a positive or negative effect on real balances (Bahmani-Oskooee \& Rehman, 2010). A depreciation of the domestic currency increases the value of foreign assets in terms of the domestic currency, and if it is perceived as an increase in wealth, it will have a positive impact on real balances. However, if the depreciation enhances expectations of further depreciation, then currency substitutions may take place and reduce real money balances (Bahmani-Oskooee \& Shin, 2002). The exchange rate variable is important in open economies' money demand function where claims denominated in foreign currency are high and currency conversion is prevalent.

Since the contribution of this paper is fairly empirical, after carefully identifying a theoretical specification with potential determinants of money demand (suggested both by a micro-founded model and the empirical literature), we attempt to search for a stable money demand function for Pakistan by applying various econometric techniques. These techniques include the residual-based cointegration approach, the autoregressive distributed lag (ARDL) modeling approach, the recursive Johansen cointegration approach, and the Bayesian estimation approach with MarkovChain Monte-Carlo (MCMC) simulations. Appendix B outlines these econometric models.

\section{Results and Discussion}

This section provides and interprets estimation results based on the four methodologies mentioned in the previous section. The variables included in all the different empirical specifications are: nominal and real money (M2), the industrial production index (IPI), real GDP, the CPI, expected inflation, the weighted average deposit rate as the own rate of broad money, weighted average six-month market treasury bills (MTBs), the ten-year bond rate (federal investment bonds [FIBs] and Pakistan investment bonds [PIBs]), the short-term interest rate spread (six-month MTB minus deposit rate), long-term interest rate spread (ten-year bond rate minus deposit rate), the weighted average lending rate, the exchange rate, and the expected depreciation of the exchange rate.

A detailed description of each variable and its data source is provided in Table C1, Appendix C. All variables are expressed in log form except the interest rate, depreciation of exchange rate, and inflation rate. The augmented Dickey-Fuller (ADF) test is used to check the stationarity of the variables (see Table C2, Appendix C). 


\subsection{Estimation Results of Engle-Granger Approach}

In this approach, we use static ordinary least squares to estimate real and nominal money demand. A simple analysis shows that the income elasticity is greater than unity for both real and nominal money demand, suggesting a relatively high flow of money in the economy (see Appendix $\mathrm{D}$, Table D1). This high income-elasticity could be due to structural changes in the economy that have resulted in large changes in currency and deposits (Adam et al., 2010).

In order to capture this structural change, we devise a principal component that includes the effect of five variables: services and manufacturing as a percent of GDP, imports and investment as a percent of GDP, government consumption as a percent of GDP, and credit to the private sector as a percent of broad money (M2) ${ }^{7}$ (see Appendix $H$, Figures H1a to H1e). Income elasticity decreases with the inclusion of the first principal component, though marginally. However, its coefficient is not significantly different from 0 , which signifies a limited structural change over this period ${ }^{8}$ (see Appendix H, Figure H1f). On the other hand, the price elasticity of nominal money is close to unity, reflecting a one-to-one relationship between the GDP deflator and M2.

To measure the opportunity cost of money demand, we use the weighted average lending rate, which is also a weak proxy for the rate of return on alternative assets because it represents the interest rate on money. This variable is introduced in view of its availability for the entire period of analysis. The interest rate coefficient carries the correct sign but its magnitude is small. Inflation, representing opportunity cost, is also included in real balances (see Appendix D, Table D1, columns 3 and 4), and has a small effect. The residual from each equation is tested for stationarity using the ADF test and the null hypothesis of nonstationarity is rejected at the 1,5 , and 10 percent levels.

A dynamic error correction model is estimated using differenced variables (with two lags) and the lag of the estimated error term. The error correction term is highly significant and has the correct sign. Its large magnitude suggests faster adjustment toward long-run equilibrium (see

\footnotetext{
${ }^{7}$ The choice of these variables is based on their transaction-intensive nature and reflects changes in the demand for liquid services (Adam et al., 2010).

${ }^{8}$ The result may be different if we were to include principal components that reflect supply-side changes. During the last two decades, particularly since 2000, the reach of the financial sector in Pakistan has increased (in terms of more branches, the entrance of foreign banks, the privatization of public banks, internet banking, ATMS, the development of the equity and bond markets, and initiation of microfinance enterprises/banks); this has significantly reduced financial costs.
} 
Appendix D, Table D2). Real and nominal money have a strong inertial effect (Table D2, columns 1 to 4). The short-run effect of real output is large but only marginally significant, while the short-term dynamic effect of opportunity cost is not significantly different from 0 .

We also estimate real and nominal money using quarterly data from 1992Q1 to 2011Q2 (see Appendix D, Table D3). Since quarterly data on real GDP is not available, we use the average of the monthly IPI instead. In the nominal demand function, the IPI coefficient is very low, signifying that it captures a small share of real output (around 15 to 18 percent). The coefficients of the CPI and lending rate are quite significant and have the expected signs. However, the estimated model is spurious and suffers from serial correlation and heteroskedasticity.

\subsection{Cointegration Results Based on ARDL Approach}

This approach considers seven alternative model specifications of the real money demand function. In all the estimated models, the coefficient of the scale variable has the correct sign and is significant, but its magnitude is less than unity as expected (see Appendix E, Table E1). In Model 1 (M-1 in Table E1), the inflation rate (representing opportunity cost) has the expected sign but a lower magnitude. The lending rate is used to proxy the rate of return on alternative assets; it has the correct sign but is not significantly different from 0 .

During the early 1990s, the financial sector underwent many changes, including the introduction of foreign currency accounts. These provided an alternative avenue for parking money, explaining why the exchange rate has a role to play in money demand. In Model 2 (M-2 in Table E1), the money demand function is estimated using the exchange rate as an additional variable; it has the correct sign but is highly insignificant. The underlying reason for this insignificance could be the volatility of the exchange rate coupled with the freezing of foreign currency accounts in 1998 and huge inflows of foreign currency in 2001 onward. These interventions in the foreign exchange market may have dampened the impact of the exchange rate.

In most money demand equations, the short-term bond rate (government's MTBs) is used to signify an alternative to money holding. Therefore, we include the weighted average rate of six-month T-bills (M-3 in Table E1) instead of the lending rate, which yields the expected sign but is insignificant; the rationale for this is that it was not used by economic agents until 2010. 
With evolving financial sector reforms, particularly in the late 1990s, the initiation of fiscal and monetary coordination-though not very effective until now-and frequent monetary policy communication has changed the economic perspective of economic agents. These agents are now more rational and take into account the economic outlook when making an economic decision. Cognizant of this changing behavior, we augment the money demand function with expected inflation and the expected depreciation of the exchange rate as potential opportunity cost variables (see M-4 in Table E1). The long-run coefficients of both variables have the expected signs and are highly significant. This may also explain the central bank's tendency to intervene frequently in the foreign exchange market in order to stabilize the exchange rate.

Since the bulk of broad money is remunerative, the own rate of M2 cannot be ignored. The weighted averaged deposit rate is used to capture the own rate of M2 (see Appendix E, Table E1, M-5 and M-6). This not only has the incorrect sign, it is also insignificant in both models. Hypothetically, the coefficient of the own rate should be positively related to money demand, i.e., an increase in the own rate should increase the demand for money (Laidler, 1993). The underlying reason for the nonresponsiveness of the own rate is the sluggish movement of deposit rates in the lowest panel of the interest rates corridor, i.e., the deposit rate is very low (until recently when a minimum floor was introduced in 2005) and barely moves in tandem with other market interest rates (M. H. Khan \& Khan, 2010).

The long-term bond market also provides an alternative avenue for the transaction demand for money. We therefore include the weighted average rate of FIBs and PIBs in our specification to examine its impact on money demand (see Appendix E, Table E1, M-6). The coefficient of the long-term bond rate has the expected sign but is not significantly different from 0 . This may be due to the fact that the long-term bond market in Pakistan is shallow and restricted: only a few large banks and financial companies are allowed to transact government bonds.

Since most market interest rates move in tandem, and including each interest rate variable in the money demand function might complicate the model and make it difficult to interpret, we include only the short-term (six-month T-bills minus deposit rate) and long-term (tenyear FIBs/PIB rate minus deposit rate) spread to capture the effect of the own rate on broad money and opportunity cost (see Appendix E, Table E1, M-7). The coefficients of the interest rate spreads have the expected sign but are insignificant. 
We also estimate the short-run dynamics of each model to examine the process of convergence toward a long-run path. The coefficient of the error correction term is significant and has the correct sign, reflecting a moderate pace of adjustment. Most of the variables in (see Appendix E, Table E2, M-1 to M-4) are significant at conventional levels and indicate a convergence toward equilibrium once they have deviated from the longrun path. On the other hand, the coefficients of the own rate, short-term rate, long-term rate, and interest rate spread are insignificant (see Appendix E, Table E2, M-5 to M-7).

\subsection{Cointegration Results Based on Johansen's Approach}

In the cointegration approach, we estimate unrestricted VAR models with various specifications of nominal and real money demand. At the outset, the variables are checked for unit roots; the ADF test confirms that all the variables are nonstationary at level and stationary at first difference, and are thus integrated of order one [I(1)] (see Appendix C, Table C2). For the model with nominal money as the dependent variable, the lag length selected under Schwarz's Bayesian criterion (SBC) and the Akaike information criterion (AIC) is $p=3$ and $p=4$, respectively. Using quarterly data from 1992Q1 to 2011Q4 and a lag length of 3 helps maintain parsimonious selection. On the other hand, in the models with real money, we select a lag length of 4 using the SBC (see Appendix F, Tables F1 and F2).

In Johansen's cointegration model, the long-run determinants of nominal M2 are the IPI, CPI, and lending rate; the determinants of real money are the IPI, expected inflation, and the lending rate. We capture the model's short-run dynamics by taking quarterly changes. This dynamism is introduced by incorporating past changes in each economic determinant in explaining M2 growth. In the short run, the determinants of nominal and real M2 growth are the last quarter's values for economic growth, inflation, and changes in interest rates. Further, past deviations of M2 from its stable long-run path are also incorporated as an explanatory variable.

The cointegration relationship is determined by using trace statistics and maximum eigenvalues. However, it is important to make certain assumptions regarding the deterministic trend specification and drift term before estimating the rank. The two specifications common in the literature are (i) a restricted intercept without a deterministic trend in a cointegration relationship and (ii) an unrestricted intercept with a linear deterministic trend in short-run equations. We use both specifications in our analysis. 
Using the specification of an unrestricted intercept and linear trend in the cointegration equation for nominal money, we find that both the trace statistics and maximum eigenvalues show one cointegrating vector. Accordingly, the estimated long-run relationship for nominal money is:

$$
\log (\mathrm{M} 2)=1.21^{*} \log (\mathrm{IPI})+1.88^{*} \log (\mathrm{CPI})-0.03^{*} \text { lending rate }-0.02^{*} \text { trend }+5.55
$$

The coefficients of all the variables are significant (see standard errors in parentheses) and have the expected signs. Income elasticity has the same magnitude as expected, i.e., more than unity. The estimated empirical realization of the adjustment parameter $(\hat{\alpha})$ in the long-run equilibrium has the following values:

$$
\hat{\alpha}=\left[\begin{array}{c}
-0.150(0.049) \\
0.351(0.129) \\
-0.075(0.019) \\
-3.785(1.161)
\end{array}\right]
$$

The first element of the column shows the error correction parameter of the estimated money demand function, which indicates a rapid adjustment toward equilibrium following a shock. The adjustment parameter changes slightly when the short-run dynamic equations for nominal money and other variables are re-parameterized to estimate projections using parsimonious relationships. Each equation is then extended by incorporating seasonal variables and the volatility of oil prices; this incorporates the short-term effects of oil price changes and the seasonal demand for money.

Similarly, for real money balances, with the specification of an unrestricted intercept without a linear deterministic trend, both the trace and eigenvalue statistics indicate one cointegrating vector. Their long-run relationship is as follows:

$\log ($ real M2 $)=0.88^{*} \log (\mathrm{IPI})-0.08^{*} \exp ($ inflation $)-0.16^{*}$ lending rate +13.75

The coefficients of all the variables are significant (see standard errors in parentheses) and have the expected signs. The vector of the adjustment parameter is as follows: 


$$
\hat{\alpha}=\left[\begin{array}{c}
-0.023(0.008) \\
-0.073(0.019) \\
-0.804(0.543) \\
0.015(0.210)
\end{array}\right]
$$

The error correction term for real money is very low, indicating slow adjustment toward long-run equilibrium. However, the error correction terms for IPI and expected inflation are relatively high, implying rapid adjustment. The ADF test indicates that the residuals of the short-run equations are stationary and normal.

A range of models of real money demand with different specifications is estimated (see Appendix F, Table F3). The lag length of the unrestricted VAR model is based on the SBC. In Models 1 to 3, we use the weighted average rate of six-month T-bills instead of the lending rate as it represents the short-term bond rate. The coefficient of the MTB rate is highly significant but has the incorrect sign. In Model 4, we include the exchange rate variable; the trace statistics indicate two cointegrating equations. Although all the long-run coefficients are significantly different from 0 , their effects are contrary to theory.

In Model 5, the MTB rate is replaced with the lending rate as an opportunity cost variable and the exchange rate included. The coefficient of the opportunity cost variable is highly significant and has the expected sign. However, the effect of the exchange rate is more pronounced, i.e., a one-percent increase in the exchange rate (depreciation) will increase real money by more than 9 percent. Nevertheless, the positive expected inflation contradicts the theory.

Model 6 includes a risk premium variable, which is the difference between the lending rate and risk-free rate (MTB rate). The coefficient of the risk premium has the expected sign but is insignificant at conventional levels. This model is extended by including the exchange rate (Model 7): in this case, all the variables, except the exchange rate, are significantly different from 0 and have the expected signs. The adjustment parameters for real money demand in all these models are either very low or explosive, signifying little or no convergence to a long-run equilibrium path.

\subsection{Bayesian Estimation Results}

The Bayesian estimation approach uses prior information on key structural parameters before taking the model and data to the simulation stage. According to Canova (2007), these reflect researchers' confidence 
about the likely location of the model's structural parameters. In practice, priors are chosen based on observation, fact, and the empirical literature.

For our study, two parameters, $\alpha$ (the share of capital in the production function) and $\beta$ (the subjective discount factor) are fixed at 0.46 and 0.99 . The parameter value of the discount factor $(\beta)$ is set in order to obtain the historical mean of the nominal interest rate in the steady state. Following Haider and Khan (2008), the degree of price stickiness $(\theta)$ is assumed to be 0.74 . This value is consistent with the latest survey-based finding on firms' optimal pricing behavior in Pakistan (see Choudhary, Naeem, Faheem, Hanif, \& Pasha, 2011). The elasticity parameter of money demand with respect to output $\left(\varphi_{1}\right)$ is taken as 0.86 whereas with respect to the interest rate $\left(\varphi_{2}\right)$ it is -0.018 . These values are consistent with ARDL long-run estimates (see Appendix E, Table E1). Prior information about other selected parameters is given in Table G1, Appendix G.

After selecting the priors, we apply Bayesian simulation algorithms by combining the likelihood distribution, which leads to an analytically intractable posterior density. In order to sample from the posteriors, we use a random walk Metropolis-Hastings algorithm to generate 150,000 draws from the posteriors. We report the posterior results (parameter estimates) in the second column of Table G2 in Appendix G. Figures G1 and G2 give the kernel estimates of the priors and the posteriors of each parameter. The results show that the prior and posterior means are not far from each other. To some extent, this confirms the stability of the money demand parameter estimates. However, we also use various formal tests of parameter stability, the results of which are discussed in the next section.

\subsection{Parameter Stability Tests}

As we observed at the estimation stage, the elasticity parameter of money demand with respect to the interest rate is sensitive to alternative specifications of money demand. Therefore, we need to test parameter stability over time for which we select the best models from each individual approach. Ideally, parameter stability should be checked using different methods, including the empirical realization of income elasticity and opportunity cost variables with a changing sample period or recursive estimations of the coefficients of each model. To verify the models' stability, we apply the CUMUS and CUMUS-square of the residual.

We first select Model 2 in the cointegrated VAR specification. This model is re-estimated using Johansen's procedure with a lag length of 4 and 
trend specification but changing the sample period, i.e., the end of each fiscal year from 2004 to 2011. The results of this recursive estimation show that income elasticity and the opportunity cost coefficients change significantlyboth in magnitude and sign-with the changing sample period, signifying an unstable money demand function (see Appendix F, Table F5).

However, when the same procedure is applied to the extended model (Model 7), the income elasticity and opportunity cost coefficients display the correct signs and are also steady over time. This confirms that the money demand function with this specification is stable. The trace statistics and maximum eigenvalues posit one or two cointegrating relationships. Figures $\mathrm{H} 3 \mathrm{a}$ and $\mathrm{H} 3 \mathrm{~b}$ in Appendix $\mathrm{H}$ show the cointegration relation estimated with Johansen's procedure using Models 2 and 7, where the former signifies instability and the latter indicates stability. The meanreverting properties are evident in the graphical representation.

Parameter consistency can also be checked by recursively estimating the coefficient of the money demand function, where coefficient of each variables $\left(\hat{\beta}_{r t}\right)$ estimated by adding more data to the equation (flexible window). Figures H4a to H4d (Appendix $\mathrm{H}$ ) show the recursively estimated log-run coefficient of Model 7 using Johansen's cointegration method. To avoid the large uncertainty associated with the initial estimates, just slightly less than half the estimates for each coefficient are displayed (from FY2006Q3 to FY2011Q2).

Figure H4a depicts stable income elasticity (around 0.7 percent) over the changing sample period. Figure $\mathrm{H} 4 \mathrm{~b}$ shows the recursive estimates of expected inflation: its coefficient remains highly stable during the initial period, but later shows significant variation and jumps markedly in FY2009. This was the period when economic conditions weakened considerably due to an uncertain domestic environment coupled with the external financial crisis and an unexpected increase in international commodity and energy prices that seeped into high domestic inflation. On the other hand, the recursive estimates of the exchange rate and risk premium remain more or less stable with slight variation in FY2009 and onward. We also recursively estimate the coefficients of the other cointegration model, but they are not stable and display large variations.

The models' stability is also tested using the CUSUM of both the residual and squared residual. We estimate the residuals recursively for all the ARDL models, where the CUSUM of the residual for Model 4 lies within a 5 percent significance level (see Appendix H, Figure H2). It is 
important to note that the ARDL model is slightly different from Model 7 (Johansen's cointegration): the exchange rate variable in the latter is replaced with the expected depreciation of the exchange rate as it is stationary at level and the ARDL procedure can be applied irrespective of a zero or one order of integration. The risk premium variable is replaced with the lending rate. Both variables in the ARDL model represent the opportunity cost of money holding.

Finally, the parameter stability of money demand in the NK-DSGE model specification is assessed using the global sensitivity toolkit. This toolkit uses the Smirnov test of stability, which shows the significance of individual parameters for the whole model. The cumulative plots for stability and instability behavior provide us with useful information on the fitness of each structural parameter. Figures H5 and H6 (see Appendix H) show that all the structural parameters of money demand are stable and properly fitted with respect to the data.

\section{Conclusion}

This study has attempted to investigate the money demand function for Pakistan, where monetary aggregates are considered a nominal anchor. Importantly, monetary aggregates as an operational and intermediate target have contributed significantly to the implementation and communication of monetary policy, but the stability of money demand has long been debated, given evolving financial innovations and regulations. Earlier studies on the subject have provided conflicting explanations due to the use of inadequate specifications and imprecise empirical estimations of the money demand function.

This study finds that money demand in Pakistan is stable if correctly specified (see ARDL Model 4, unrestricted cointegrated VAR Model 7, and NK-DSGE model) and concludes that monetary aggregates should remain, if not the primary, the secondary targets in the monetary policy framework. Although financial innovations have changed the preferences of economic agents (money holders) in developed countries, they have had a limited impact on economic behavior in developing countries such as Pakistan. 


\section{References}

Abe, S., Fry, M. J., Min, B. K., Vongvipanond, P., \& Yu, T. (1975). The demand for money in Pakistan: Some alternative estimates. Pakistan Development Review, 14(2), 249-257.

Adam, C. S., Kessy, P. J., Nyella, J. J., \& O'Connell, S. A. (2010). The demand for money in Tanzania (Mimeo). London, UK: International Growth Centre.

Ahmad, M., \& Khan, A. H. (1990). A reexamination of the stability of the demand for money in Pakistan. Journal of Macroeconomics, 12(2), 307-321.

Ahmed, W., Haider, A., \& Iqbal, J. (2012). A guide for developing countries on estimation of discount factor and coefficient of relative risk aversion (Mimeo). Karachi: State Bank of Pakistan.

Akhtar, M. A. (1974). The demand for money in Pakistan. Pakistan Development Review, 13(1), 39-54.

Arrau, P., De Gregorio, J., Reinhart, C., \& Wickham, P. (1995). The demand for money in developing countries: Assessing the role of financial innovation. Journal of Development Economics, 46(2), 317-340.

Azim, P., Ahmed, N., Ullah, S., Zaman, B., \& Zakaria, M. (2010). Demand for money in Pakistan: An ARDL approach. Global Journal of Management and Business Research, 10(9), 76-80.

Bahmani-Oskooee, M., \& Ng, R. C. W. (2002). Long-run demand for money in Hong Kong: An application of the ARDL model. International Journal of Business and Economics, 1(2), 147-155.

Bahmani-Oskooee, M., \& Rehman, H. (2010). Stability of the money demand function in Asian developing countries. Applied Economics, 37(7), 773-792.

Bahmani-Oskooee, M., \& Shin, S. (2002). Stability of the demand for money in Korea. International Economic Journal, 16(2), 85-95.

Bahmani-Oskooee, M., \& Wang, Y. (2007). How stable is the demand for money in China? Journal of Economic Development, 32(1), 21-33. 
Belke, A., \& Czudaj, R. (2010). Is euro area demand (still) stable? Cointegrated VAR versus single equation techniques (Discussion Paper No. 982). Berlin, Germany: German Institute for Economic Research.

Bernanke, B. (2006). Monetary aggregates and monetary policy at the Federal Reserve: A historical perspective. Address at the $4^{\text {th }}$ ECB Central Banking Conference, Frankfurt, Germany.

Brand, C., \& Cassola, N. (2000). A money demand system for euro area M3 (Working Paper No. 39). Frankfurt, Germany: European Central Bank.

Browne, F. X., Fagan, G., \& Henry, J. (1997). Money demand in EU countries: A survey (Staff Paper No. 7). Frankfurt, Germany: European Monetary Institute.

Bruggeman, A., Donati, P., \& Warne, A. (2003). Is the demand for euro area M3 stable? (Working Paper No. 255). Frankfurt, Germany: European Central Bank.

Calza, A., Gerdesmeier, D., \& Levy, J. (2001). Euro area money demand: Measuring the opportunity costs appropriately (Working Paper No. 01/179). Washington, DC: International Monetary Fund.

Calza, A., \& Sousa, J. (2003). Why has broad money demand been more stable in the euro area than in other economies? A literature review (Working Paper No. 261). Frankfurt, Germany: European Central Bank.

Canova, F. (2007). Methods for applied macroeconomic research. Princeton, NJ: Princeton University Press.

Cho, D. W., \& Miles, W. (2004). Financial innovation and the stability of money demand in Korea. Southwestern Economic Review, 20, 51-60.

Choudhary, A., Naeem, S., Faheem, A., Hanif, N., \& Pasha, F. (2011). Formal sector price discoveries: Preliminary results from a developing country (Working Paper No. 42). Karachi: State Bank of Pakistan.

Coenen, G., \& Vega, J. (1999). The demand for M3 in the euro area (Working Paper No. 6). Frankfurt, Germany: European Central Bank. 
Cuthbertson, K., \& Galindo, L. (1999). The demand for money in Mexico. The Manchester School, 67(2), 154-166.

Dickey, D. A., \& Fuller, W. A. (1979). Distribution of the estimators for autoregressive time series with a unit root. Journal of the American Statistical Association, 74, 427-431.

Dickey, D. A., \& Fuller, W. A. (1981). Likelihood ratio statistics for autoregressive time series with a unit root. Econometrica, 49(4), 1057-1072.

Ericsson, N. R. (1992). Cointegration, exogeneity, and policy analysis: An overview. Journal of Policy Modeling, 14(3), 251-280.

Ericsson, N. R. (1998). Empirical modeling of money demand. Empirical Economics, 23(3), 295-315.

Ericsson, N. R., Hendry, D. F., \& Prestwich, K. M. (1997). The demand for broad money in the United Kingdom, 1878-1993 (International Finance Discussion Paper No. 596). Washington, DC: Board of Governors of the Federal Reserve System.

Enders, W. (2010). Applied econometric time series analysis (3rd ed.). New York, NY: John Wiley and Sons.

Engle, R., \& Granger, C. (1987). Cointegration and error correction: Representation, estimation, and testing. Econometrica, 55(2), 251276.

Friedman, M. (1956). The quantity theory of money: A restatement. In M. Friedman (ed.), Studies in the quantity theory of money, 3-21. Chicago, IL: University of Chicago Press.

Galí, J. (2008). Monetary policy, inflation and the business cycle: An introduction to the new Keynesian framework. Princeton, NJ: Princeton University Press.

Gelman, A., Carlin, J. B., Stern, H. S., \& Rubin, D. B. (2006). Bayesian data analysis (2nd ed.). London, UK: Chapman and Hall.

Golinelli, R., \& Pastorello, S. (2002). Modeling the demand for M3 in the euro area. European Journal of Finance, 8(4), 371-401. 
Haider, A., \& Khan, S. U. (2008). A small open economy DSGE model for Pakistan. Pakistan Development Review, 47(4), 963-1008.

Heller, H. R., \& Khan, M. S. (1979). The demand for money and the term structure of interest rates. Journal of Political Economy, 87, 109-129.

Hossain, A. (1994). The search for a stable money demand function for Pakistan: An application of the method of cointegration. Pakistan Development Review, 33(4), 969-983.

Johansen, S. (1988). Statistical analysis of cointegration vectors. Journal of Economic Dynamics and Control, 12, 231-254.

Johansen, S., \& Juselius, K. (1990). Maximum likelihood estimation and inference on cointegration-with applications to the demand for money. Oxford Bulletin of Economics and Statistics, 52(2), 169-210.

Khan, A. H. (1980). The demand for money in Pakistan: Some further results. Pakistan Development Review, 19(1), 25-50.

Khan, A. H. (1982). Adjustment mechanism and the money demand function in Pakistan. Pakistan Economic and Social Review, 20, 36-51.

Khan, I. N. (1992). The demand for money in Pakistan and India. Pakistan Economic and Social Review, 30(2), 181-190.

Khan, M. H., \& Khan, B. (2010). What drives interest rate spreads of commercial banks in Pakistan? Empirical evidence based on panel data. State Bank of Pakistan Research Bulletin, 6(2), 15-36.

Khan, M. S. (1974). The stability of the demand-for-money function in the United States 1901-1965. Journal of Political Economy, 82(6), 12051219.

Koop, G., Poirier, D. J., \& Tobias, J. L. (2007). Bayesian econometric methods. Cambridge, UK: Cambridge University Press.

Laidler, D. (1993). The demand for money: Theories, evidence and problems (4th ed.). London, UK: HarperCollins.

Lieberman, C. (1977). The transactions demand for money and technological change. Review of Economics and Statistics, 59, 307-317. 
Mishkin, F. S. (1995). Symposium on the monetary transmission mechanism. Journal of Economic Perspectives, 9(4), 3-10.

Mishkin, F. S. (2000). International experiences with different monetary policy regimes (Working Paper No. 7044). Cambridge, MA: National Bureau of Economic Research.

Moinuddin. (2009). Choice of monetary policy regime: Should the SBP adopt inflation targeting? State Bank of Pakistan Research Bulletin, 5(1), 1-30.

Narayan, P. K., Narayan, S., \& Mishra, V. (2009). Estimating demand function for South Asian countries. Empirical Economics, 36, 685-696.

Nisar, S., \& Aslam, N. (1983). The demand for money and the term structure of the interest rates in Pakistan. Pakistan Development Review, 22(2), 97-116.

Omer, M. (2010). Stability of money demand function in Pakistan (Working Paper No. 36). Karachi: State Bank of Pakistan.

Omer, M., \& Saqib, O. F. (2009). Monetary targeting in Pakistan: A skeptical note. State Bank of Pakistan Research Bulletin, 5(1), 53-81.

Pesaran, M. H., \& Shin, Y. (1995). An autoregressive distributed lag modeling approach to cointegration analysis. In S. Strom, A. Holly, \& P. Diamond (Eds.), Centennial volume of Ragnar Frisch. Cambridge, UK: Cambridge University Press.

Pesaran, M. H., Shin, Y., \& Smith, R. J. (2001). Bounds testing approaches to the analysis of level relationships. Journal of Applied Econometrics, 16(3), 289-326.

Pesaran, M. H., \& Pesaran, B. (1997). Working with Microfit 4.0: Interactive econometric analysis. Oxford, UK: Oxford University Press.

Qayyum, A. (1998). Error correction model of the demand for money in Pakistan. Kashmir Economic Review, 6(1-2), 53-65.

Qayyum, A. (2005). Modeling the demand for money in Pakistan. Pakistan Development Review, 44(3), 233-252. 
Ratto, M. (2007). Analyzing DSGE models with global sensitivity analysis. Computational Economics, 31, 115-139.

Skrabic, B., \& Tomic-Plazibat, N. (2009). Evidence of the long-run equilibrium between money demand determinants in Croatia. Proceedings of the World Academy of Science, Engineering and Technology, 49, 578.

State Bank of Pakistan. (n.d.). Financial stability review. Karachi: Author.

Valadkhani, A. (2002). Long- and short-run determinants of the demand for money in New Zealand: A cointegration analysis. New Zealand Economic Papers, 36(2), 235-250.

Walsh, C. E. (2010). Monetary theory and policy (3rd ed.). Cambridge, MA: MIT Press.

Woodford, M. (1998). Doing without money: Controlling inflation in a post-monetary world. Review of Economic Dynamics, 1, 173-219.

Woodford, M. (2008). How important is money in the conduct of monetary policy? Journal of Money, Credit and Banking, 40(8), 1561-1598. 


\section{Appendix A}

\section{Theoretical Foundations of the Money Demand Function}

This section deals with the micro-foundations of the standard money demand function. To derive the theoretical specification, we consider a typical new Keynesian DSGE model as given in Galí (2008) and Walsh (2010). The model setup starts with households' optimal decision to maximize their intertemporal utility function subject to a lifetime budget constraint. The utility function depends on consumption,, leisure, , and real money balances. Firms, on the other hand, produce output by using labor as a standard input of production and attempt to maximize profit in a monopolistic competitive fashion. Other agents include the central bank, which conducts monetary policy, and the government, which deals with fiscal policy-related issues.

Since we are interested in the theoretical specification of money demand, we start with household optimization. The lifetime utility function is:

$$
U_{0}=E_{t} \sum_{i=0}^{\infty} \beta^{i} u\left[C_{t+i},\left(1-l_{t+i}\right), \frac{M_{t+i}}{P_{t+i}}\right]
$$

where is the subjective discount factor. For analytical simplicity, the utility function is assumed to be separable and is specified as:

$$
u\left[C_{t+i},\left(1-l_{t+i}\right), \frac{M_{t+i}}{P_{t+i}}\right]=\frac{\left(C_{t+i}\right)^{1-\gamma}}{1-\gamma}+\frac{\left(1-l_{t+i}\right)^{1-v}}{1-v}+\frac{\xi_{m, t+i}}{1-\omega}\left(\frac{M_{t+i}}{P_{t+i}}\right)^{1-\omega}
$$

where is the parameter of risk aversion, is the inverse elasticity of labor supply, is the inverse interest elasticity of money demand, and is a stochastic shock to money demand. The other usual assumptions regarding the utility function are: $\partial \partial$ and $\partial \partial$, which implies that it is increasing but diminishing over time in each case. Households want to maximize this utility function subject to the following budget constraint:

$$
C_{t}+\frac{M_{t}}{P_{t}}+\frac{B_{t}}{P_{t}}=\frac{W_{t}}{P_{t}} l_{t}+\frac{M_{t-1}}{P_{t}}+\left(1+i_{t-1}\right) \frac{B_{t-1}}{P_{t}}+\Pi_{\mathrm{t}}
$$

where denotes the general price level, is interest-bearing assets with as the nominal gross return on assets at time, is nominal labor income, and is real dividends. 
The household optimization process solves the following problem as:



where is the Lagrange multiplier associated with the household budget constraint. The solution to this optimization process yields the following first-order conditions (FOCs):

$$
\begin{aligned}
& C_{t}^{-\gamma}=\lambda_{t} \\
& \xi_{m, t}\left(\frac{M_{t}}{P_{t}}\right)^{-\omega}=\lambda_{t}\left(1-\beta E_{t} \frac{\lambda_{t+1}}{\lambda_{t}} \frac{P_{t}}{P_{t+1}}\right) \\
& \left(1-l_{t}\right)^{-v}=\frac{W_{t}}{P_{t}} \lambda_{t} \\
& 1=\beta\left(1+i_{t}\right) E_{t}\left(\frac{\lambda_{t+1}}{\lambda_{t}} \frac{P_{t}}{P_{t+1}}\right)
\end{aligned}
$$

We define the gross inflation rate as . Solving the above FOCs simultaneously yields two important results.

The first is the intertemporal Euler equation of consumption:

$$
1=\beta \frac{\left(1+i_{t}\right)}{\left(1+\pi_{t+1}\right)} E_{t}\left(\frac{C_{t}}{C_{t+1}}\right)^{\gamma}
$$

The second is the nonlinear money demand function:

$$
\xi_{m, t}\left(\frac{M_{t}}{P_{t}}\right)^{-\omega}=C_{t}^{-\gamma}\left(\frac{i_{t}}{1+i_{t}}\right)
$$

The economy-wide aggregate resource constraint in the model can be written as Therefore, the final nonlinear version of the money demand function can be simplified as:

$$
\xi_{m, t}\left(\frac{M_{t}}{P_{t}}\right)^{-\omega}=Y_{t}^{-\gamma}\left(\frac{i_{t}}{1+i_{t}}\right)
$$


For empirical estimation purposes, we consider the linear version of this money demand function. It can be log-linearized around the deterministic steady-state using first-order Taylor approximation and any linearized variable can be defined as $\tilde{x}_{t}=\log \left(x_{t}\right)-\log (\bar{x})$.

$$
1+\tilde{\xi}_{m, t}+(-\omega) \overline{\left(\frac{M_{t}}{P_{t}}\right)}=1-\gamma \widetilde{Y}_{t}+\tilde{\imath}_{t}
$$

or

$$
\overline{\left(\frac{M_{t}}{P_{t}}\right)}=\frac{\gamma}{\omega}\left(\widetilde{Y_{t}}\right)-\frac{1}{\omega}\left(\tilde{l}_{t}\right)+\frac{1}{\omega}\left(\tilde{\xi}_{m, t}\right)
$$

If we consider, $\varphi_{1}=\frac{\gamma}{\omega^{\prime}} \varphi_{2}=-\frac{1}{\omega}$ and $\tilde{\varepsilon}_{m, t}=\frac{1}{\omega}\left(\tilde{\xi}_{m, t}\right)$, where, $\varphi_{1}$ is the output elasticity of money demand according to the restriction on deep parameters, it appears to be positive while is negative. This signifies that money demand is positively related to output and negatively to nominal interest rates. The final simplified linear version of money demand with the inclusion of an interest term, for econometric consideration, is given as:

$$
\widetilde{\left(\frac{M_{t}}{P_{t}}\right)}=\varphi_{0}+\varphi_{1}\left(\widetilde{Y_{t}}\right)+\varphi_{2}\left(\tilde{l}_{t}\right)+\tilde{\varepsilon}_{m, t}
$$




\section{Appendix B}

\section{Econometric Modeling Setups}

This study estimates the money demand for Pakistan with different specifications in light of a theoretical micro-founded model and the empirical literature. Accordingly, we apply various econometric techniques to analyze whether money demand is stable. More specifically, we consider the residual-based cointegration approach (Engle \& Granger, 1987), the ARDL approach (Pesaran \& Shin, 1995; Pesaran, Shin, \& Smith, 2001), the recursive Johansen cointegration approach (Johansen, 1988; Johansen \& Juselius, 1990), and the Bayesian estimation approach with MCMC simulations (Canova, 2007).

\section{B.1. Engle-Granger Modeling Setup}

From the theoretical model derived in Section 3, we have the following standard linear specification of the money demand function:

$$
\widetilde{\left(\frac{M_{t}}{P_{t}}\right)}=\varphi_{0}+\varphi_{1}\left(\widetilde{Y_{t}}\right)+\varphi_{2}\left(\tilde{l}_{t}\right)+\tilde{\varepsilon}_{m, t}
$$

This specification suggests that real money demand depends on real output and the nominal interest rate, where $\varphi_{1}$ and $\varphi_{2}$ are the elasticity parameters of money demand with respect to output and the interest rate. However, in practice, econometricians have attempted to estimate both nominal and real versions of the money demand function. The nominal version considers actual inflation an explanatory variable while the real money demand function takes expected inflation as a possible determinant to tackle future expectations. The literature argues that, due to structural changes in currency and deposits in developing economies, the income elasticity of money demand will be high (see, for instance, Adam et al., 2010).

In order to tackle this possible empirical issue, we construct an index of structural change based on the principal component technique. This index includes the effect of five variables: services and manufacturing as a percent of GDP, imports and investment as a percent of GDP, government consumption as a percent of GDP, and credit to the private sector as a percent of broad money (M2). This variable is then augmented as an explanatory variable in both regressions of money demand. Thus, we have the following four specifications: 
Nominal money demand:

$\widetilde{\left(M_{t}\right)}=\varphi_{0}^{S 1}+\varphi_{1}^{S 1}\left(\widetilde{Y_{t}}\right)+\varphi_{2}^{S 1}\left(\tilde{l}_{t}\right)+\varphi_{3}^{S 1}\left(\tilde{\pi}_{t}\right)+\tilde{\varepsilon}_{M, t}^{S 1}$

$(\mathrm{EG}-\mathrm{S} 1)$

$\widetilde{\left(M_{t}\right)}=\varphi_{0}^{S 2}+\varphi_{1}^{S 2}\left(\widetilde{Y_{t}}\right)+\varphi_{2}^{S 2}\left(\tilde{l}_{t}\right)+\varphi_{3}^{S 2}\left(\tilde{\pi}_{t}\right)+\varphi_{4}^{S 2}($ StructChange $)+\tilde{\varepsilon}_{M, t}^{S 2} \quad(\mathrm{EG}-\mathrm{S} 2)$

Real money demand:

$\overline{\left(\frac{M_{t}}{P_{t}}\right)}=\varphi_{0}^{S 3}+\varphi_{1}^{S 3}\left(\widetilde{Y_{t}}\right)+\varphi_{2}^{S 3}\left(\tilde{l}_{t}\right)+\varphi_{3}^{S 3}\left(\tilde{\pi}_{t}^{e}\right)+\tilde{\varepsilon}_{m, t}^{S 3}$

$\widetilde{\left(\frac{M_{t}}{P_{t}}\right)}=\varphi_{0}^{S 4}+\varphi_{1}^{S 4}\left(\widetilde{Y_{t}}\right)+\varphi_{2}^{S 4}\left(\tilde{l}_{t}\right)+\varphi_{3}^{S 4}\left(\tilde{\pi}_{t}^{e}\right)+\varphi_{4}^{S 4}\left(\right.$ StructChange $\left.e_{t}\right)+\tilde{\varepsilon}_{m, t}^{S 4}$

Where, as usual, $\left[\varphi_{1}^{S 1}, \varphi_{1}^{S 2}, \varphi_{1}^{S 3}\right.$, and $\left.\varphi_{1}^{S 4}\right]>0$ and $\left[\varphi_{2}^{S 1}, \varphi_{2}^{S 2}, \varphi_{2}^{S 3}\right.$, and $\left.\varphi_{2}^{S 4}\right]<0$ are the long-run elasticities of income and the interest rate, and can be estimated using static ordinary least squares (SOLS).

In order to test the long-run dynamics, we need to check the stationarity of each variable. Once we have confirmed that the selected series are integrated and of the same order, we apply the Engle-Granger test of cointegration. This test checks the stationarity of the estimated residuals of each specification. If an estimated residual is stationary at level, we can conclude that long-run dynamics exist. Using the Granger representation theorem, any cointegrated regression can be mapped onto its error correction mechanism (ECM), which deals with short-run dynamics.

In general, the ECM version of any of the above specifications can be written as:

$$
\Delta \widetilde{z_{t}}=\alpha+\beta \widetilde{E C M_{t-1}}+\sum_{i=1}^{p-1} \gamma_{i} \Delta \widetilde{z_{t-l}}+\sum_{i=1}^{p-1} \Psi_{i} \Delta \widetilde{\Upsilon_{t-l}}+\tilde{\varepsilon}_{z, t}
$$

where $\beta \in(-1,0)$, is the short-run correction parameter. One important shortcoming of the Engle-Granger cointegration test based on SOLS is that the estimates have an asymptotic distribution, that is, they are generally non-Gaussian and exhibit a large sample bias. Since conventional testing procedures are not valid unless modified substantially, SOLS is generally inappropriate for making inferences about the cointegrating vector. For this reason, we use ARDL VAR models for cointegration and Bayesian simulation approaches. 


\section{B.2. ARDL Modeling Setup}

Pesaran and Shin (1995) and Pesaran et al. (2001) have developed a bounds test using ARDL to find the long-run relationship between variables irrespective of their order of integration. ${ }^{1}$ This technique does not require pretesting the unit roots of the variables as the ADF unit root test become redundant in the presence of structural breaks. It allows us to estimate the cointegration relationship with OLS once the lag order to the model is identified. Therefore, in general, we can write the $\operatorname{VAR}(\mathrm{p})$ model as:

$$
\widetilde{Y}_{t}=b+c t+\sum_{i=1}^{p} \Phi_{i} \tilde{Y}_{t-i}+\tilde{\varepsilon}_{Y, t}
$$

where $\widetilde{Y}_{t}$ represents a vector of variables. The above expression can be written as a simple VECM:

$$
\Delta \widetilde{Y}_{t}=B+C t+\Theta \tilde{Y}_{t-1}+\sum_{i=1}^{p-1} \Gamma_{i} \Delta \tilde{Y}_{t-i}+\tilde{\varepsilon}_{Y, t}
$$

Where, $\Theta=-\left(\mathrm{I}_{\mathrm{k}+1}-\sum_{i=1}^{p} \Phi_{i}\right)$ and $\Gamma_{i}=-\sum_{j=i+1}^{p} \Phi_{j}, i=1, \ldots, p-1$; are the $(k+1) \times(k+1)$ matrices of the long run multipliers and the short run dynamic coefficients. By making the assumption that there is only one long run relationship amongst the variables, Pesaran and Shin (1995) and Pessaran et al., (2001) focus on the VECM equation and partition $\widetilde{Y_{t}}$ into a dependant variable, $\widetilde{z_{t}}$ and a set of forcing variables, $\widetilde{X_{t}}$. Under such conditions, the matrices $B, C, \Gamma$ and, most importantly, $\Theta$, the long run multiplier matrix can also be partitioned conformably with the partitioning of $\widetilde{Y}_{t}$.

$$
\Theta=\left(\begin{array}{ll}
\theta_{11} & \theta_{12} \\
\theta_{21} & \theta_{22}
\end{array}\right) \quad B=\left(\begin{array}{l}
b_{1} \\
b_{2}
\end{array}\right) \quad C=\left(\begin{array}{l}
c_{1} \\
c_{2}
\end{array}\right) \quad \Gamma=\left(\begin{array}{ll}
\gamma_{11} & \gamma_{12} \\
\gamma_{21} & \gamma_{22}
\end{array}\right)
$$

The key assumption, that $\widetilde{X_{t}}$ is long run forcing for $\widetilde{z_{t}}$, then implies that the vector, $\theta_{21}=0$, that is that there is no feedback from the level of $\widetilde{z_{t}}$ on $\Delta \widetilde{X_{t}}$. As a result, the conditional model for $\Delta \widetilde{z_{t}}$ and $\Delta \widetilde{X_{t}}$ can be written as:

$\Delta \widetilde{z_{t}}=b_{1}+c_{1} t+\theta_{11} \tilde{z}_{t-1}+\theta_{12} \tilde{X}_{t-1}+\sum_{i=1}^{p-1} \gamma_{11, i} \Delta \tilde{z}_{t-i}+\sum_{i=1}^{p-1} \gamma_{12, i} \Delta \tilde{X}_{t-i}+\tilde{\varepsilon}_{1, t}$

\footnotetext{
${ }^{1}$ This technique is applicable to variables that are either stationary at level or integrated of order one. However, the relationship becomes explosive when one or all the variables are of high order, i.e., $\mathrm{I}(2)$.
} 


$$
\Delta \widetilde{X_{t}}=b_{2}+c_{2} t+\theta_{22} \tilde{X}_{t-1}+\sum_{i=1}^{p-1} \gamma_{21, i} \Delta \tilde{z}_{t-i}+\sum_{i=1}^{p-1} \gamma_{22, i} \Delta \tilde{X}_{t-i}+\tilde{\varepsilon}_{2, t}
$$

Under standard assumptions about the error terms in above representations, ${ }^{2}$ Pessaran et al., (2001) re-write the system as:

$$
\Delta \widetilde{z_{t}}=\alpha_{1}+\alpha_{2} t+\phi \tilde{z}_{t-1}+\delta \tilde{X}_{t-1}+\sum_{i=1}^{p-1} v_{i} \Delta \tilde{z}_{t-i}+\sum_{i=1}^{p-1} \varphi_{i} \Delta \tilde{X}_{t-i}+\tilde{\varepsilon}_{t}
$$

They term this an unrestricted error correction model. Note that, in this expression, a long-run relationship will exist among the level variables if the two parameters $\phi$ and $\delta$ are both non-zero, in which case, for the longrun solution, we obtain:

$$
\widetilde{z_{t}}=-\frac{\alpha_{1}}{\phi}-\frac{\alpha_{2}}{\phi} t-\frac{\delta}{\phi} \tilde{X}_{t}
$$

Pesaran et al. (2001) choose to test the hypothesis of no long-run relationship between $\widetilde{z_{t}}$ and $\widetilde{X_{t}}$ by testing the joint hypothesis that $\phi=\delta=0$ in the context of the above VECM. The test they develop is a bounds-type test with a lower bound calculated on the basis that the variables in $\widetilde{X_{t}}$ are $\mathrm{I}(0)$ and an upper bound calculated on the basis that they are I(1). They provide critical values for this test from an extensive set of stochastic simulations under differing assumptions regarding the appropriate inclusion of deterministic variables in the ECM.

If the calculated test statistic (which is a standard F-test for testing the null hypothesis that the coefficients on the lagged levels' terms are jointly equal to 0) lies above the upper bound, the result is conclusive and implies that a long-run relationship does exist between the variables. If the test statistic lies within the bounds, no conclusion can be drawn without prior knowledge of the time series properties of the variables. In this case, standard methods of testing have to be applied. If the test statistic lies below the lower bound, no long-run relationship exists.

We estimate the money demand function based on the following general form:

2 Essentially that they are independently normally distributed with a positive definite variance covariance matrix. 
$\Delta \widetilde{\left(\frac{M_{t}}{P_{t}}\right)}=\alpha_{1}+\alpha_{2} t+\phi\left(\widetilde{\left.\frac{M_{t-1}}{P_{t-1}}\right)}+\delta \tilde{X}_{t-1}+\sum_{i=1}^{p-1} v_{i} \Delta \widetilde{\left(\frac{M_{t-l}}{P_{t-l}}\right)}+\sum_{i=1}^{p-1} \varphi_{i} \Delta \tilde{X}_{t-i}+\tilde{\varepsilon}_{t}\right.$

where $\widetilde{X_{t}}$ is a set of exogenous variables. We attempt seven alternative specifications of the ARDL model to test the underlying stability hypothesis. The main objective is to correctly identify the real money demand function and to determine the long-run relationship vis-à-vis the short-run dynamic. The vector of exogenous variables in each specification is listed below:

$\widetilde{X_{t}}=[$ industrial output; weighted avg. lending rate; inflation $]$

(ARDL-S1)

$\widetilde{X_{t}}=[$ industrial output; weighted avg. lending rate; inflation; exch. rate $]$

(ARDL-S2)

$\widetilde{X_{t}}=[$ industrial output; six-month T-bill rate; expected inflation $]$

$\widetilde{X_{t}}=$ [industrial output; weighted avg. lending rate; expected inflation; exch. rate]

$\widetilde{X_{t}}=[$ industrial output; own rate; six-month T-bill rate; inflation $]$

$\widetilde{X_{t}}=[$ industrial output; own rate; six-month T-bill rate; ten-year bond rate; inflation $]$

$\widetilde{X_{t}}=[$ industrial output; risk premium; expected inflation; exch. rate $]$

These specifications are applied to quarterly data from 1991Q1 to 2011Q4 for the following variables: the IPI as a scale variable, the opportunity cost variable CPI inflation (QoQ), the exchange rate, the variant interest rate, i.e., the lending rate, the six-month treasury bond rate, the long-term rate (weighted average of ten-year FIBs/PIBs), the short-term interest rate spread, and the long-term interest rate spread. We also consider the weighted average of the deposit rate as the own rate of broad money (M2). The SBC is applied to select a lag order for each model.

\section{B.3. Johansen Modeling Setup}

This setup is an extension of the Engle-Granger modeling framework in a VAR fashion, and also follows the assumption that all the series are integrated of the same order. The starting point is similar to that of the ARDL setup with the construction of a VAR(p) model as follows:

$$
\widetilde{Y}_{t}=b+c t+\sum_{i=1}^{p} \Phi_{i} \tilde{Y}_{t-i}+\tilde{\varepsilon}_{Y, t}
$$

where $\widetilde{Y}_{t}$ represents a vector of variables of the same order of integrationlet us say, I(1). The above expression can be written as a simple VECM: 


$$
\Delta \widetilde{Y}_{t}=B+C t+\Theta \tilde{Y}_{t-1}+\sum_{i=1}^{p-1} \Gamma_{i} \Delta \tilde{Y}_{t-i}+\tilde{\varepsilon}_{Y, t}
$$

Where, $\Theta=-\left(\mathrm{I}_{\mathrm{k}+1}-\sum_{i=1}^{p} \Phi_{i}\right)$ and $\Gamma_{i}=-\sum_{j=i+1}^{p} \Phi_{j}, i=1, \ldots, p-1$; are the $(k+1) \times(k+1)$ matrices of the long run multipliers and the short run dynamic coefficients. Since, $\Delta \tilde{Y}_{t-i}, \ldots, \Delta \tilde{Y}_{t-i+1}$ are I(0) but $\tilde{Y}_{t-1}$, is I(1). So in order to do this equation consistent, $\Gamma_{i}$ should not be of full rank. Consider its rank is $\mathrm{r}<(k+1)$. We can decompose matrix, $\Theta=\alpha \beta^{\prime}$, where, $\alpha$ is $(k+1) \times r$ matrix of error correction terms (speed of adjustment parameters) and $\beta^{\prime}$ is $r \times(k+1)$ matrix of coefficients of cointegrating vector. Now, we need to estimate two residual series, first by regressing, $\Delta \widetilde{Y}_{t}$ on $\sum_{i=1}^{p-1} \Gamma_{i} \Delta \widetilde{Y}_{t-i}$ and name it $\xi_{o, t}$ and second by regressing $\widetilde{Y}_{t}$ on $\sum_{i=1}^{p-1} \Gamma_{i} \Delta \tilde{Y}_{t-i}$ and name it, $\xi_{i, t}$. Now, in next step, we form a regression on estimated residuals as: $\xi_{o, t}=\alpha \beta^{\prime} \xi_{i, t}+\varsigma_{t}$. The variance/co-variance matrix of this regression can be written as:

$$
\Omega=\left(\begin{array}{ll}
S_{00} & S_{01} \\
S_{10} & S_{11}
\end{array}\right)
$$

where $S_{11}$ is the sum of the squares of $\xi, S_{00}$ is the sum of the squares of $\xi$ and $S_{01}$ is the sum of the product of $\xi$ and $\xi$. It is important to note that OLS is not applicable to estimating VAR because of cross-equation restrictions. We therefore use the maximum likelihood technique, where the maximum of the likelihood function is obtained by solving the eigenvalue problem:

$$
\left|S_{10} S_{00}^{-1} S_{01}-\lambda S_{11}\right|=0
$$

This is equivalent to finding the eigenvalue of. We can then obtain the eigenvalues that are the root of this equation. These represent the $\gamma$ canonical correlation between $\xi$ and $\xi$. Thus, the maximum of the likelihood function is given by:

$$
-2 \log L \max \left\{\alpha N \sum_{i=1}^{k+1} \ln \left(1-\lambda_{i}\right)\right\}
$$

Using this expression, we can define the trace test statistic and maximum eigenvalue as:

$$
\lambda_{\text {trace }}=-N \sum_{i=1}^{k+1} \ln \left(1-\widehat{\lambda}_{l}\right)
$$

and 


$$
\lambda_{\max }(r, r+1)=-N \ln \left(1-\hat{\lambda}_{r+1}\right)
$$

The null hypothesis of the maximum eigenvalue test is $\gamma$ cointegrating vector(s), whereas the alternative hypothesis is $\gamma+1$ cointegrating vector(s).

To apply this modeling procedure to the estimation and stability of the money demand function, we consider seven alternative specifications:

$\widetilde{Y}_{t}=[$ real.m2;Industiral.Output; Weighted Avg.Ledning Rate; Inflation $] \quad$ (Johansen-S1)

$\widetilde{Y}_{t}=[$ real.m2;Industiral.Output; Weighted Avg.Ledning Rate; Expected Inflation $]$ (Johansen-S2)

$\widetilde{Y}_{t}=$ [real.m2;Industiral.Output; 6-month.TBill.Rate; Expected Inflation $] \quad$ (Johansen-S3)

$\widetilde{Y}_{t}=$ [real.m2;Industiral.Output; 6-month.TBill.Rate; Expected Inflation;Exch.Rate $]$ (Johansen-S4)

$\widetilde{Y}_{t}=$ [real.m2;Industiral.Output; Weighted Avg.Ledning Rate; Inflation,Exch.Rate $]$ (Johansen-S5)

$\widetilde{Y}_{t}=$ [real.m2;Industiral.Output; Risk Premium; Inflation $] \quad$ (Johansen-S6)

$\widetilde{Y}_{t}=[$ real.m2;Industiral.Output; Risk Premium; Expected Inflation;Exch.Rate $] \quad$ (Johansen-S7)

To estimate the short-run dynamics of the money demand function, we extract VECMs for each specification for which the dependent variable is real money demand as follows:

$\Delta \widetilde{\left(\frac{M_{t}}{P_{t}}\right)}=\alpha_{1}+\alpha_{2} t+\phi\left(\widetilde{\left.\frac{M_{t-1}}{P_{t-1}}\right)}+\delta \tilde{X}_{t-1}+\sum_{i=1}^{p-1} v_{i} \Delta \widetilde{\left(\frac{M_{t-l}}{P_{t-l}}\right)}+\sum_{i=1}^{p-1} \varphi_{i} \Delta \tilde{X}_{t-i}+\tilde{\varepsilon}_{t}\right.$

\section{B.4. Bayesian Modeling Setup}

In order to estimate the money demand function using the Bayesian estimation approach, we consider the complete new Keyensian monetary model in log-linearzed form as derived in Section 3. ${ }^{3}$ This model consists of six structural equations: (i) forward-looking IS equation, (ii) new Keynesian Phillips curve, (iii) production function, (iv) money demand equation, (v) evolution of the natural rate of interest, and (vi) Taylor-type monetary policy rule. Furthermore, three stochastic shocks-a productivity shock, money demand shock, and monetary policy shock-are taken into account. The outline of the NK model is given as follows:

$$
\begin{aligned}
& \tilde{y}_{t}=E\left(\tilde{y}_{t+1}\right)-\frac{1}{\gamma}\left(\tilde{l}_{t}-E \tilde{\pi}_{t+1}-\tilde{r}_{t}^{n}\right) \\
& \tilde{\pi}_{t}=\beta E\left(\tilde{\pi}_{t+1}\right)+\kappa \tilde{y}_{t}
\end{aligned}
$$

\footnotetext{
${ }^{3}$ For simplicity, we have not provided the micro-foundations of the supply side (firms and the cost channel of monetary policy). These derivations are available on request.
} 
Where, $\kappa=\frac{(1-\theta)(1-\beta \theta)}{\theta}$ is slope of NKPC.

$$
\begin{array}{lr}
\tilde{r}_{t}^{n}=\rho+\gamma \psi\left(\rho_{a}-1\right) \tilde{a}_{t} & \text { [Eq. of Natural Rate of interest] } \\
\widetilde{y}_{t}=\tilde{a}_{t}+(1-\alpha) \tilde{l}_{t} & \text { [Eq. of production function] } \\
\widetilde{m}_{t}=\varphi_{1}\left(\widetilde{Y_{t}}\right)+\varphi_{2}\left(\tilde{l}_{t}\right)+\tilde{\varepsilon}_{m, t} & \text { [Eq. of real money demand] } \\
\tilde{\iota}_{t}=\rho+\chi_{1}\left(\widetilde{\pi_{t}}\right)+\chi_{2}\left(\tilde{Y}_{t}\right)+\tilde{\varepsilon}_{i, t} & \text { [Monetary policy rule] } \\
\widetilde{a}_{t}=\rho_{a} \widetilde{a}_{t-1}+\xi_{a, t} & \text { [Productivity Shock] } \\
\widetilde{\varepsilon}_{m, t}=\rho_{m} \widetilde{\varepsilon}_{m, t-1}+\xi_{m, t} & \text { [Money demand shock] } \\
\widetilde{\varepsilon}_{i, t}=\rho_{i} \widetilde{\varepsilon}_{i, t-1}+\xi_{i, t} & \text { [Monetary policy Shock] }
\end{array}
$$

Following Canova (2007), we try to fit this model, which consists of placing a prior distribution on the structural parameters, , the estimates of which are then updated using the data according to the Bayes rule:

$$
p\left(\frac{\Gamma}{Y^{T}}\right)=\frac{p\left(\frac{Y^{T}}{\Gamma}\right)}{p\left(Y^{T}\right)} \propto L\left(\frac{\Gamma}{Y^{T}}\right) p(\Gamma)
$$

where $p\left(\frac{Y^{T}}{\Gamma}\right)=L\left(\frac{\Gamma}{Y^{T}}\right)$ is the likelihood function, $p\left(\frac{\Gamma}{Y^{T}}\right)$ is the posterior distribution of parameters, and is the marginal likelihood defined as:

$$
p\left(Y^{T}\right)=\int p\left(\frac{Y^{T}}{\Gamma}\right) p(\Gamma) d \Gamma
$$

Any NK model will form a linear system with rational expectations, the solution to which takes the form

$$
\begin{aligned}
& R_{t}=B_{1}(\Gamma) R_{t-1}+B_{2}(\Gamma) \mu_{t} \\
& \mu_{t}=B_{3}(\Gamma) \mu_{t-1}+B_{4}(\Gamma) \varepsilon_{t}
\end{aligned}
$$

where $R_{t}$ is a vector of endogenous variables, $\mu_{t}$ is a vector of stochastic disturbances, and $\varepsilon_{t}$ is a vector of innovations to stochastic shocks and coefficient matrices $A_{i}$ depending on the parameters of the model. 
The measurement equations linking the observable variables used in the estimation with the endogenous variables can be written as, where $C$ is the deterministic matrix. The equations' expressions form the state-space representation of the model, the likelihood of which can be evaluated using the Kalman filter. An analytical solution to the whole system may not be obtainable in general, but the sequence of posterior draws can be obtained using the MCMC simulation methodology (see Gelman, Carlin, Stern, \& Rubin, 2006; Koop, Poirier, \& Tobias, 2007). Finally, the random walk Metropolis-Hastings algorithm is used to generate Morkov chains for the model parameters.

After obtaining the Bayesian estimation results, we use the global sensitivity analysis (GSA) toolkit ${ }^{4}$ to assess the fitness and stability of the model's structural parameters. This toolkit consists of MATLAB routines, which use the Smirnov test for stability analysis. Ratto (2007) provides a detailed discussion on using this toolkit with various applied examples.

${ }^{4}$ http://www.dynare.org 


\section{Appendix C}

\section{Results}

Table C1: Variables and data sources

\begin{tabular}{|c|c|}
\hline Variables & Source \\
\hline Nominal M2 & $\begin{array}{l}\text { Statistical Bulletins, SBP } \\
\text { (various issues) }\end{array}$ \\
\hline Real GDP (Annual data) & $\begin{array}{l}\text { Pakistan Economic Survey, MOF } \\
\text { (various issues) }\end{array}$ \\
\hline Industrial production index (IPI) & $\begin{array}{l}\text { Statistical Bulletins, SBP } \\
\text { (various issues) }\end{array}$ \\
\hline Consumer price index (CPI) & $\begin{array}{l}\text { Statistical Bulletins, SBP } \\
\text { (various issues) }\end{array}$ \\
\hline Inflation (percent change in CPI) & $\begin{array}{l}\text { Statistical Bulletins, SBP } \\
\text { (various issues) }\end{array}$ \\
\hline Exchange rate & $\begin{array}{l}\text { Statistical Bulletins, SBP } \\
\text { (various issues) }\end{array}$ \\
\hline ER App/dep (+/-) & $\begin{array}{l}\text { Statistical Bulletins, SBP } \\
\text { (various issues) }\end{array}$ \\
\hline Lending rate & $\begin{array}{l}\text { Statistical Bulletins, SBP } \\
\text { (various issues) }\end{array}$ \\
\hline Own rate (wt. avg. deposit rate) & $\begin{array}{l}\text { Statistical Bulletins, SBP } \\
\text { (various issues) }\end{array}$ \\
\hline Short-term rate (wt. avg. 6-month MTB) & $\begin{array}{l}\text { Statistical Bulletins, SBP } \\
\text { (various issues) }\end{array}$ \\
\hline Long-term rate (wt. avg. 10-year FIB/PIB) & $\begin{array}{l}\text { Statistical Bulletins, SBP } \\
\text { (various issues) }\end{array}$ \\
\hline Risk premium (lending rate - MTB) & $\begin{array}{l}\text { Statistical Bulletins, SBP } \\
\text { (various issues) }\end{array}$ \\
\hline Short-term spread (6-month MTB - deposit rate) & $\begin{array}{l}\text { Statistical Bulletins, SBP } \\
\text { (various issues) }\end{array}$ \\
\hline Long-term spread (10-year bond - deposit rate) & $\begin{array}{l}\text { Statistical Bulletins, SBP } \\
\text { (various issues) }\end{array}$ \\
\hline
\end{tabular}

Note: SBP = State Bank of Pakistan, MOF = Ministry of Finance. 
Table C2: Unit root test

\begin{tabular}{|c|c|c|c|c|c|c|}
\hline \multirow[b]{2}{*}{ Variables } & \multicolumn{3}{|c|}{ Augmented Dickey-Fuller test } & \multicolumn{3}{|c|}{ Dickey-Fuller GLS test } \\
\hline & Level & Difference & $\begin{array}{c}\text { Order of } \\
\text { integration }\end{array}$ & Level & Difference & $\begin{array}{c}\text { Order of } \\
\text { integration }\end{array}$ \\
\hline Nominal M2 & -0.423 & $-2.004^{* *}$ & $\mathrm{I}(1)$ & -0.423 & $-2.004^{* *}$ & $\mathrm{I}(1)$ \\
\hline Real M2 & -1.810 & $-8.811^{*}$ & $\mathrm{I}(1)$ & -0.848 & $-8.702^{*}$ & $\mathrm{I}(1)$ \\
\hline $\begin{array}{l}\text { Real GDP (annual } \\
\text { data) }\end{array}$ & -0.724 & $-6.366^{*}$ & $\mathrm{I}(1)$ & 0.749 & $-6.156^{*}$ & $\mathrm{I}(1)$ \\
\hline IPI & -1.934 & $-13.432^{*}$ & $\mathrm{I}(1)$ & -1.012 & $-7.278^{*}$ & $\mathrm{I}(1)$ \\
\hline CPI & 1.567 & $-3.6315^{*}$ & $\mathrm{I}(1)$ & 0.977 & $-3.284^{*}$ & $\mathrm{I}(1)$ \\
\hline Inflation & -2.556 & $-5.545^{*}$ & $\mathrm{I}(1)$ & -0.978 & $-3.380^{*}$ & $\mathrm{I}(1)$ \\
\hline $\log$ (exchange rate) & -0.300 & $-3.435^{* *}$ & $\mathrm{I}(1)$ & 0.161 & $-3.393^{*}$ & $\mathrm{I}(1)$ \\
\hline ER depreciation & $-3.435^{* *}$ & - & $\mathrm{I}(0)$ & $-3.416^{*}$ & - & $\mathrm{I}(0)$ \\
\hline Lending rate & -1.483 & $-3.369^{*}$ & $\mathrm{I}(1)$ & -1.452 & $-2.977^{*}$ & $\mathrm{I}(1)$ \\
\hline $\begin{array}{l}\text { Own rate (wt. avg. } \\
\text { deposit rate) }\end{array}$ & -1.838 & -2.228 & $\mathrm{I}(1)$ & -0.527 & $-2.047^{* *}$ & $\mathrm{I}(1)$ \\
\hline $\begin{array}{l}\text { Short-term rate } \\
\text { (wt. avg. 6-month } \\
\text { MTB) }\end{array}$ & -1.274 & $-3.916^{*}$ & $\mathrm{I}(1)$ & -1.341 & $-2.605^{* *}$ & $\mathrm{I}(1)$ \\
\hline $\begin{array}{l}\text { Long-term rate } \\
\text { (wt. avg. 10-year } \\
\text { FIB/PIB) }\end{array}$ & -1.942 & $-3.490^{* *}$ & $\mathrm{I}(1)$ & -1.481 & $-3.532^{*}$ & $\mathrm{I}(1)$ \\
\hline $\begin{array}{l}\text { Risk premium } \\
\text { (lending rate - } \\
\text { MTB) }\end{array}$ & -1.913 & $-5.380^{*}$ & $\mathrm{I}(1)$ & -0.801 & $-3.592^{*}$ & $\mathrm{I}(1)$ \\
\hline $\begin{array}{l}\text { Short-term spread } \\
\text { (6-month MTB - } \\
\text { deposit rate) }\end{array}$ & -2.49156 & $-6.779 *$ & $\mathrm{I}(1)$ & $-2.270^{* *}$ & - & $\mathrm{I}(0)$ \\
\hline $\begin{array}{l}\text { Long-term spread } \\
\text { (10-year bond - } \\
\text { deposit rate) }\end{array}$ & -2.356 & $-5.715^{*}$ & $\mathrm{I}(1)$ & $-2.011^{* *}$ & - & $\mathrm{I}(0)$ \\
\hline
\end{tabular}

Note: Level of significance $=^{*}$ at $1 \%,{ }^{* *}$ at $5 \%$, and ${ }^{* * *}$ at $10 \%$. Critical values are from Mackinnon (1996). SBC is used for lag selection. Test estimation includes intercept. All variables are in log form except variant of interest rate, exchange rate depreciation, and inflation. 


\section{Appendix D}

\section{Engle-Granger Modeling Results}

Table D1: Long-run static estimation of money demand (based on annual data)

Dependent variable: Log of broad money (sample range: 1978 to 2011)

\begin{tabular}{lcccc}
\hline \multirow{2}{*}{ Regressors } & \multicolumn{2}{c}{ Nominal money } & \multicolumn{2}{c}{ Real money } \\
\cline { 2 - 5 } & $\mathbf{( 1 )}$ & $\mathbf{( 2 )}$ & $\mathbf{( 3 )}$ & $\mathbf{( 4 )}$ \\
\hline Log(GDP real) & 1.24 & 1.13 & 1.26 & 1.14 \\
$\log$ (GDP deflator) & $(7.54)$ & $(7.32)$ & $(59.35)$ & $(24.2)$ \\
& 0.98 & 1.00 & & \\
Lending rate & $(9.61)$ & $(10.31)$ & & \\
& -0.02 & -0.01 & -0.01 & -0.01 \\
Inflation (averaged) & $(-2.79)$ & $(-2.08)$ & $(-2.18)$ & $(-1.81)$ \\
& & & -0.01 & -0.002 \\
Structural changes & & & $(-2.65)$ & $(-1.0)$ \\
& & 0.03 & & 0.03 \\
Constant & & $(0.22)$ & & $(1.58)$ \\
& -8.96 & -7.48 & -4.55 & -2.92 \\
Adj. R ${ }^{2}$ & $(-4.31)$ & $(-3.87)$ & $(-14.9)$ & $(-4.32)$ \\
DW & 0.99 & 0.99 & 0.99 & 0.99 \\
ADF of residual & 1.25 & 1.07 & 0.81 & 0.90 \\
Serial corr./hetro. & $-4.22^{*}$ & $-3.3^{* *}$ & $-2.74^{* * *}$ & $-2.97^{* *}$ \\
\hline
\end{tabular}

Note: $\mathrm{t}$-statistics in parenthesis. ${ }^{*}, * * * * *=$ significant at $1 \%, 5 \%$, and $10 \%$, respectively. First principal component represents structural change. 
Table D2: Error correction models of broad money (based on annual data, sample: 1973-2011)

\begin{tabular}{|c|c|c|c|c|}
\hline \multirow[b]{2}{*}{ Dependent variable/regression } & \multicolumn{2}{|c|}{$\mathrm{D}(\log (\mathrm{M} 2)$} & \multicolumn{2}{|c|}{ D(Log(real M2) } \\
\hline & (1) & (2) & (3) & (4) \\
\hline $\mathrm{ECM}_{(\mathrm{t}-1)}$ & $\begin{array}{c}-0.63 \\
(-4.49)\end{array}$ & $\begin{array}{c}-0.75 \\
(-3.65)\end{array}$ & $\begin{array}{c}-0.50 \\
(-4.10)\end{array}$ & $\begin{array}{l}-0.61 \\
(-4.18)\end{array}$ \\
\hline $\mathrm{D}(\mathrm{LOG}(\mathrm{M} 2(-1)))$ & $\begin{array}{c}0.64 \\
(3.91)\end{array}$ & $\begin{array}{c}0.70 \\
(3.64)\end{array}$ & & \\
\hline $\mathrm{D}(\mathrm{LOG}(\mathrm{M} 2(-2)))$ & $\begin{array}{c}0.19 \\
(1.29)\end{array}$ & $\begin{array}{l}0.28 \\
(1.42)\end{array}$ & & \\
\hline $\mathrm{D}(\mathrm{LOG}($ real M2(-1))) & & & $\begin{array}{c}060 \\
(4.80)\end{array}$ & $\begin{array}{c}064 \\
(3.91)\end{array}$ \\
\hline $\mathrm{D}(\mathrm{LOG}($ real M2(-2))) & & & $\begin{array}{c}0.18 \\
(1.61)\end{array}$ & \\
\hline $\mathrm{D}(\mathrm{LOG}(\mathrm{YR}))$ & $\begin{array}{l}0.75 \\
(2.77)\end{array}$ & $\begin{array}{c}0.54 \\
(1.41)\end{array}$ & $\begin{array}{l}0.56 \\
(2.15)\end{array}$ & $\begin{array}{l}1.20 \\
(3.25)\end{array}$ \\
\hline $\mathrm{D}$ ( INF) & & & $\begin{array}{c}-0.01 \\
(-5.30)\end{array}$ & $\begin{array}{c}-0.01 \\
(-4.36)\end{array}$ \\
\hline $\mathrm{D}(\mathrm{LR}(-1))$ & & $\begin{array}{c}-0.01 \\
(-1.52)\end{array}$ & & \\
\hline $\mathrm{D}(\mathrm{LR}(-2))$ & $\begin{array}{c}0.01 \\
(1.49)\end{array}$ & $\begin{array}{c}0.01 \\
(1.84)\end{array}$ & $\begin{array}{c}0.01 \\
(1.19)\end{array}$ & $\begin{array}{c}0.01 \\
(1.71)\end{array}$ \\
\hline $\mathrm{D}$ (structural change) & & $\begin{array}{c}0.05 \\
(1.73)\end{array}$ & & \\
\hline $\mathrm{D}$ (structural change $(-2)$ & & & & $\begin{array}{c}0.01 \\
(0.63)\end{array}$ \\
\hline Constant & $\begin{array}{l}-0.01 \\
(-0.40)\end{array}$ & $\begin{array}{c}-0.03 \\
(-0.77)\end{array}$ & $\begin{array}{l}-0.01 \\
(-0.78)\end{array}$ & $\begin{array}{c}-0.04 \\
(-1.92)\end{array}$ \\
\hline Adj. $R^{2}$ & 0.43 & 0.39 & 0.65 & 0.67 \\
\hline SE & 0.03 & 0.03 & 0.03 & 0.03 \\
\hline F-statistic & $\begin{array}{c}5.61 \\
{[0.001]}\end{array}$ & $\begin{array}{c}3.53 \\
{[0.01]}\end{array}$ & $\begin{array}{l}11.41 \\
{[0.00]}\end{array}$ & $\begin{array}{l}10.43 \\
{[0.00]}\end{array}$ \\
\hline DW & 1.87 & 1.95 & 1.97 & \\
\hline
\end{tabular}

Note: t-statistics in parentheses. Structural change is the first principal component. 
Table D3: Long-run static estimation of money demand (based on quarterly data)

Dependent variable: Log of M2 (sample range: 1992Q1-2011Q4)

\begin{tabular}{lcccc}
\hline & \multicolumn{2}{c}{ Nominal money } & \multicolumn{2}{c}{ Real money } \\
\cline { 2 - 5 } Regressors & $\mathbf{( 1 )}$ & $\mathbf{( 2 )}$ & $\mathbf{( 3 )}$ & $\mathbf{( 4 )}$ \\
\hline $\log (\mathrm{IPI})$ & 0.35 & 0.35 & 0.98 & 0.53 \\
& $(6.61)$ & $(6.13)$ & $(22.48)$ & $(9.53)$ \\
$\log (\mathrm{CPI})$ & 1.53 & 1.53 & & \\
& $(37.44)$ & $(16.89)$ & & -0.02 \\
Lending rate & -0.02 & -0.02 & -0.01 & $(-4.66)$ \\
& $(-7.63)$ & $(-7.19)$ & $(-0.89)$ & -0.004 \\
Inflation (Q/Q) & & & -0.01 & $(-1.75)$ \\
& & & $(-1.78)$ & 0.47 \\
Log(ER) & & 0.01 & & $(9.53)$ \\
& & $(0.94)$ & & 10.1 \\
Constant & 5.84 & 5.84 & 9.64 & $(59.84)$ \\
\hline Adj. R 2 & $(41.43)$ & $(38.08)$ & $(40.06)$ & 0.95 \\
DW & 0.99 & 0.99 & 0.89 & 1.10 \\
ADF of residual & 0.74 & 0.75 & 1.45 & $-5.5^{*}$ \\
Standard error & $-4.22^{*}$ & $-4.28^{*}$ & $-2.74^{*}$ & 0.08 \\
Serial corr./hetro. & 0.07 & 0.07 & 0.12 & yes \\
\hline
\end{tabular}

Note: t-statistics in parentheses. ${ }^{*} * *$, and ${ }^{* * *}=$ significant at $1 \%, 5 \%$, and $10 \%$. 


\section{Appendix E}

\section{ARDL Modeling Results}

Table E1: Long-run relationship of real money (ARDL approach) Dependent variable: log real M2 (sample range: 1992Q1-2011Q4)

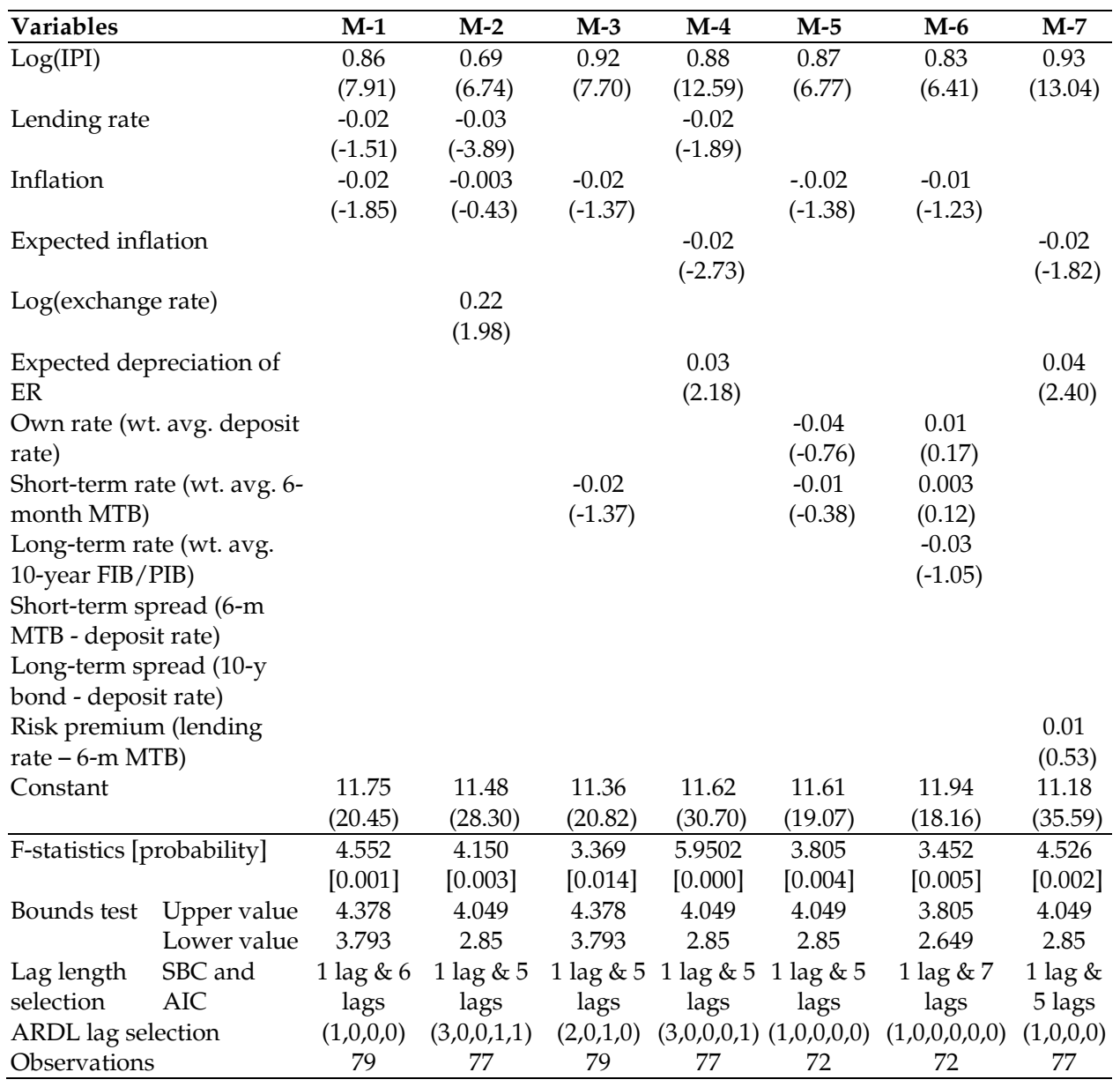

Note: SBC is used to select the optimum number of lags in the ARDL model. 
Table E2: Short-run error correction model

Dependent variable: $\Delta$ log real M2 (sample range: 1992Q1-2011Q4)

\begin{tabular}{|c|c|c|c|c|c|c|c|}
\hline Variables & M-1 & M-2 & M-3 & M-4 & M-5 & M-6 & M-7 \\
\hline$\overline{\mathrm{ECM}}_{(-1)}$ & $\begin{array}{l}-0.10 \\
(-3.49)\end{array}$ & $\begin{array}{c}-0.17 \\
(-4.55)\end{array}$ & $\begin{array}{c}-0.09 \\
(-2.65)\end{array}$ & $\begin{array}{l}-0.12 \\
(-4.92)\end{array}$ & $\begin{array}{c}-0.10 \\
(-2.71)\end{array}$ & $\begin{array}{l}-0.11 \\
(-2.89)\end{array}$ & $\begin{array}{c}-0.11 \\
(-4.53)\end{array}$ \\
\hline DLIPIA & $\begin{array}{c}0.09 \\
(2.91)\end{array}$ & $\begin{array}{c}0.11 \\
(4.77)\end{array}$ & $\begin{array}{l}0.09 \\
(2.58)\end{array}$ & $\begin{array}{c}0.11 \\
(4.36)\end{array}$ & $\begin{array}{l}0.09 \\
(2.51)\end{array}$ & $\begin{array}{c}0.09 \\
(2.59)\end{array}$ & $\begin{array}{c}0.11 \\
(4.14)\end{array}$ \\
\hline DLR & $\begin{array}{l}-0.002 \\
(-1.61)\end{array}$ & $\begin{array}{l}-0.004 \\
(-3.09)\end{array}$ & & $\begin{array}{l}-0.002 \\
(-1.84)\end{array}$ & & & \\
\hline DINF & $\begin{array}{l}-0.002 \\
(-1.89)\end{array}$ & $\begin{array}{c}-0.01 \\
(-3.23)\end{array}$ & $\begin{array}{l}-0.002 \\
(-1.57)\end{array}$ & & $\begin{array}{l}-0.002 \\
(-1.57)\end{array}$ & $\begin{array}{l}-0.002 \\
(-1.37)\end{array}$ & \\
\hline D Exp(INF) & & & & $\begin{array}{l}-0.002 \\
(-2.80)\end{array}$ & & & $\begin{array}{l}-0.002 \\
(-1.90)\end{array}$ \\
\hline DLER & & $\begin{array}{l}-0.29 \\
(2.70)\end{array}$ & & & & & \\
\hline D EXP(ER) & & & & $\begin{array}{l}0.001 \\
(0.46)\end{array}$ & & & $\begin{array}{l}0.001 \\
(0.87)\end{array}$ \\
\hline $\mathrm{D}$ (own rate) & & & & & $\begin{array}{l}-0.003 \\
(-0.77)\end{array}$ & $\begin{array}{l}0.001 \\
(0.17)\end{array}$ & \\
\hline $\begin{array}{l}\text { D short-term } \\
\text { (6-m MTBs) }\end{array}$ & & & $\begin{array}{l}-0.001 \\
(-1.21)\end{array}$ & & $\begin{array}{l}-0.000 \\
(-0.004)\end{array}$ & $\begin{array}{l}0.0002 \\
(0.12)\end{array}$ & \\
\hline $\begin{array}{l}\text { D long-term } \\
\text { (10-y bond } \\
\text { rate) }\end{array}$ & & & & & & $\begin{array}{l}-0.004 \\
(-1.02)\end{array}$ & \\
\hline DLRM21 & & $\begin{array}{c}-0.45 \\
(-4.41)\end{array}$ & & $\begin{array}{c}-0.49 \\
(-4.77)\end{array}$ & & & $\begin{array}{c}-0.42 \\
(-4.24)\end{array}$ \\
\hline DLRM22 & & $\begin{array}{c}0.29 \\
(3.01)\end{array}$ & & $\begin{array}{c}0.24 \\
(2.48)\end{array}$ & & & $\begin{array}{c}0.32 \\
(3.47)\end{array}$ \\
\hline $\begin{array}{l}\mathrm{D} \text { (risk } \\
\text { premium) }\end{array}$ & & & & & & & $\begin{array}{l}0.001 \\
(0.53)\end{array}$ \\
\hline Constant & $\begin{array}{r}1.21 \\
(3.73) \\
\end{array}$ & $\begin{array}{c}1.91 \\
(4.81) \\
\end{array}$ & $\begin{array}{r}1.07 \\
(2.68) \\
\end{array}$ & $\begin{array}{r}1.43 \\
(5.12) \\
\end{array}$ & $\begin{array}{r}1.14 \\
(2.78) \\
\end{array}$ & $\begin{array}{r}1.29 \\
(2.96) \\
\end{array}$ & $\begin{array}{r}1.27 \\
(4.70) \\
\end{array}$ \\
\hline$\overline{\text { Adj. } R^{2}}$ & 0.15 & 0.56 & 0.11 & 0.53 & 0.10 & 0.1 & 0.51 \\
\hline F-statistics & $\begin{array}{c}\mathrm{F}(4,74) \\
7.35[0.003]\end{array}$ & $\begin{array}{c}\mathrm{F}(5,69) \\
15.4[0.00]\end{array}$ & $\begin{array}{c}\mathrm{F}(4,68) \\
3.18[0.02]\end{array}$ & $\begin{array}{c}\mathrm{F}(7,69) \\
13.46[0.00]\end{array}$ & $\begin{array}{c}\mathrm{F}(5,66) \\
2.60[0.033]\end{array}$ & $\begin{array}{c}\mathrm{F}(6,65) \\
2.34[0.014]\end{array}$ & $\begin{array}{c}F(7,69) \\
12.45[0.00]\end{array}$ \\
\hline
\end{tabular}

Table E3: Forecasting of broad money

\begin{tabular}{lccccccc}
\hline & M1 & M-2 & M-3 & M-4 & M-5 & M-6 & M-7 \\
\hline Q1-FY11 & $2.58 \%$ & $0.77 \%$ & $3.23 \%$ & $0.49 \%$ & $3.00 \%$ & $3.08 \%$ & $1.12 \%$ \\
Q2-FY11 & $1.88 \%$ & $6.08 \%$ & $2.76 \%$ & $6.74 \%$ & $2.63 \%$ & $2.16 \%$ & $7.1 \%$ \\
Q3-FY11 & $2.95 \%$ & $2.54 \%$ & $2.18 \%$ & $0.80 \%$ & $2.05 \%$ & $1.71 \%$ & $1.4 \%$ \\
Q4-FY11 & $2.21 \%$ & $3.48 \%$ & $2.23 \%$ & $4.19 \%$ & $2.15 \%$ & $1.82 \%$ & $4.77 \%$ \\
\hline FY11 & $10.0 \%$ & $13.43 \%$ & $10.82 \%$ & $12.66 \%$ & $10.20 \%$ & $9.07 \%$ & $15.11 \%$ \\
\hline
\end{tabular}

Note: For forecasting purposes, we use the actual data on CPI averaged inflation (13.7), averaged lending rate $(13.9 \%)$, IPI growth $(0.4 \%)$, expected depreciation $(-0.8 \%)$, and M2 growth (15.89) for FY2011. 


\section{Appendix F}

\section{Johansen Modeling Results}

\section{Table F1: VAR lag order selection criteria}

Endogenous variables: LOG(M2) LOG(IPIA) LOG(CPIA) LR

Exogenous variables: Constant, sample 1991Q1 to 2011Q4, observations $=74$

\begin{tabular}{lcccccc}
\hline Lag & LogL & LR & FPE & AIC & SC & HQ \\
\hline 0 & -67.973 & NA & 0.000 & 2.027 & 2.155 & 2.078 \\
1 & 352.744 & 782.178 & 0.000 & -9.373 & -8.736 & -9.120 \\
2 & 440.986 & 154.112 & 0.000 & -11.408 & -10.261 & -10.952 \\
3 & 475.577 & 56.515 & 0.000 & -11.932 & $-10.275^{*}$ & -11.273 \\
4 & 508.812 & $50.556^{*}$ & $4.94 \mathrm{e}-11^{*}$ & $-12.417^{*}$ & -10.250 & $-11.556^{*}$ \\
5 & 520.439 & 16.375 & 0.000 & -12.294 & -9.617 & -11.230 \\
6 & 527.591 & 9.268 & 0.000 & -12.045 & -8.858 & -10.778 \\
7 & 548.447 & 24.675 & 0.000 & -12.182 & -8.485 & -10.712 \\
\hline
\end{tabular}

Note: * indicates lag order selected by the criterion.

$\mathrm{LR}=$ sequential modified LR test statistic (each test at 5\% level), HQ = Hannan-Quinn information criteria. $\mathrm{FPE}=$ final prediction error, $\mathrm{AIC}=$ Akaike information criterion, $\mathrm{SC}=$ Schwarz information criterion.

\section{Table F2: VAR lag order selection criteria}

Endogenous variables: LOG(RM2) LOG(IPIA) INF(1) LR

Exogenous variables: Constant, sample 1992Q1 to 2011Q4, observations $=74$

\begin{tabular}{lcccccc}
\hline Lag & LogL & LR & FPE & AIC & SC & HQ \\
\hline 0 & -336.383 & NA & 0.171486 & 9.588 & 9.716 & 9.639 \\
1 & 7.800 & 639.890 & $1.66 \mathrm{E}-05$ & 0.344 & 0.981 & 0.597 \\
2 & 81.685 & 129.038 & $3.26 \mathrm{E}-06$ & -1.287 & -0.140 & -0.831 \\
3 & 111.799 & 49.201 & $2.22 \mathrm{E}-06$ & -1.684 & -0.027 & -1.025 \\
4 & 154.695 & $65.250^{*}$ & $1.06 \mathrm{e}-06^{*}$ & -2.442 & $-0.275^{*}$ & $-1.580^{*}$ \\
5 & 171.856 & 24.171 & $1.06 \mathrm{E}-06$ & $-2.475^{*}$ & 0.202 & -1.410 \\
6 & 181.227 & 12.142 & $1.35 \mathrm{E}-06$ & -2.288 & 0.899 & -1.021 \\
7 & 194.098 & 15.228 & $1.59 \mathrm{E}-06$ & -2.200 & 1.497 & -0.730 \\
\hline
\end{tabular}

Note: * indicates lag order selected by the criterion.

$\mathrm{LR}=$ sequential modified LR test statistic (each test at 5\% level), HQ = Hannan-Quinn information criteria. $\mathrm{FPE}=$ final prediction error, $\mathrm{AIC}=$ Akaike information criterion, $\mathrm{SC}=$ Schwarz information criterion. 
Table F3: Money demand function with different specifications Dependent variable: $\log ($ real M2), Sample: 1992Q1 to 2011Q2

\begin{tabular}{|c|c|c|c|c|c|}
\hline \multirow[b]{2}{*}{ Model } & \multirow[b]{2}{*}{ Estimated long-run relation } & \multirow{2}{*}{$\begin{array}{l}\text { SBC/AIC } \\
\text { lag- } \\
\text { length }\end{array}$} & \multicolumn{3}{|c|}{ Cointegration } \\
\hline & & & $\begin{array}{c}\text { Trend } \\
\text { specifications }\end{array}$ & Trace & $\begin{array}{c}\text { Max. } \\
\text { eigenvalue }\end{array}$ \\
\hline 1 & $\begin{array}{l}\log (\mathrm{M} 2)=1.21^{*} \log (\mathrm{IPI})+ \\
1.88^{*} \log (\mathrm{CPI})-0.03^{*} \text { Lending } \\
\text { rate }-0.02^{*} \text { trend }+5.55\end{array}$ & $2 \& 4$ & $\begin{array}{l}\text { Unrestricted } \\
\text { intercept with linear } \\
\text { deterministic trend }\end{array}$ & 1 & 1 \\
\hline 2 & $\begin{array}{l}\log (\text { real M2 })=0.88^{*} \log (\mathrm{IPI})- \\
\left.0.08^{*} \text { Exp(inflation }\right)- \\
0.16^{*} \text { Lending rate }+13.75\end{array}$ & $4 \& 5$ & $\begin{array}{l}\text { Restricted intercept } \\
\text { without trend }\end{array}$ & 1 & 1 \\
\hline 3 & $\begin{array}{l}\log (\mathrm{RM} 2)=1.13^{*} \mathrm{LOG}(\mathrm{IPI})+ \\
0.05^{*} \operatorname{Exp}(\text { Inflation })+0.06^{*} \mathrm{MTB} \\
+9.05\end{array}$ & $4 \& 4$ & $\begin{array}{l}\text { Restricted intercept } \\
\text { without trend }\end{array}$ & 1 & 0 \\
\hline 4 & $\begin{array}{l}\log (\mathrm{RM} 2)=-1.53^{*} \mathrm{LOG}(\mathrm{IPI}) \\
+2.52^{*} \mathrm{ER}+0.07^{*} \operatorname{Exp}(\text { Inflation })- \\
0.02^{*} \mathrm{MTB}-0.05^{*} \text { trend }-0.07\end{array}$ & $2 \& 7$ & $\begin{array}{l}\text { Unrestricted } \\
\text { intercept with linear } \\
\text { deterministic trend }\end{array}$ & 2 & 1 \\
\hline 5 & $\begin{array}{l}\log (\mathrm{RM} 2)=1.25^{*} \mathrm{LOG}(\mathrm{IPI})+ \\
0.02^{*} \operatorname{Exp}(\text { Inflation })+ \\
1.16^{*} \log (\mathrm{ER})-0.02^{*} \mathrm{LR}- \\
0.02^{*} \text { trend }-5.99\end{array}$ & $2 \& 5$ & $\begin{array}{l}\text { Unrestricted } \\
\text { intercept with linear } \\
\text { deterministic trend }\end{array}$ & 1 & 1 \\
\hline 6 & $\begin{array}{l}\log (\mathrm{RM} 2)=0.48^{*} \mathrm{LOG}(\mathrm{IPI})+ \\
0.002^{*} \operatorname{Exp}(\text { Inflation })-0.01^{*} \text { Risk } \\
+0.01^{*} \text { trend }+12.4\end{array}$ & $3 \& 5$ & $\begin{array}{l}\text { Unrestricted } \\
\text { intercept with linear } \\
\text { deterministic trend } \\
\end{array}$ & 1 & 2 \\
\hline 7 & $\begin{array}{l}\log (\mathrm{RM} 2)=1.38^{*} \mathrm{LOG}(\mathrm{IPI})- \\
0.08^{*} \operatorname{Exp}(\text { Inflation })- \\
0.34^{*} \log (\mathrm{ER})-0.11^{*} \text { Risk }+11.23\end{array}$ & $2 \& 7$ & $\begin{array}{l}\text { Restricted intercept } \\
\text { without linear } \\
\text { deterministic trend }\end{array}$ & 1 & 2 \\
\hline
\end{tabular}

Note: Weighted average rate of 6-month MTB, lending rate (LR), averaged exchange rate $(\mathrm{ER})$, risk = LR - MTB. 
Table F4: Estimation of money demand (Johansen procedure)

\begin{tabular}{lccccc}
\hline Sample end & & & & \multicolumn{2}{c}{ Cointegration } \\
${ } }$ & $\boldsymbol{\eta}_{\text {ipi }}$ & $\boldsymbol{\eta}_{\text {E(inf) }}$ & $\boldsymbol{\eta}_{\text {LR }}$ & Trace & $\begin{array}{c}\text { Max. } \\
\text { eigenvalue }\end{array}$ \\
\hline FY05-Q4 & -3.10 & -0.02 & -0.21 & 1 & 1 \\
& $(-1.58)$ & $(-0.76)$ & $(-4.08)$ & & 1 \\
FY06-Q4 & -2.06 & -0.04 & -0.31 & 3 & 1 \\
& $(-0.92)$ & $(-1.18)$ & $(-3.97)$ & & \\
FY07-Q4 & -0.13 & -0.11 & -0.48 & 4 & 1 \\
& $(-0.05)$ & $(-1.57)$ & $(-4.94)$ & & 1 \\
FY08-Q4 & -0.19 & -0.002 & -0.11 & 1 & 1 \\
& $(-0.32)$ & $(-0.09)$ & $(-4.98)$ & & 1 \\
FY09-Q4 & 0.45 & 0.02 & -0.04 & 1 & 1 \\
& $(1.68)$ & $(-3.28)$ & $(4.18)$ & & 1 \\
FY10-Q4 & -0.41 & 0.08 & 0.20 & 1 & 1 \\
& $(-0.38)$ & $(3.33)$ & $(4.35)$ & & \\
FY11-Q4 & 0.88 & -0.08 & -0.16 & 2 & \\
& $(4.27)$ & $(-3.69)$ & $(-4.45)$ & & \\
\hline
\end{tabular}

Table F5: Estimation of money demand (Johansen procedure)

\begin{tabular}{lcccccc}
\hline $\begin{array}{c}\text { Sample end } \\
\text { period }\end{array}$ & $\boldsymbol{\eta}_{\text {ipi }}$ & $\boldsymbol{\eta}_{\text {E(inf) }}$ & $\boldsymbol{\eta}_{\text {ER }}$ & $\boldsymbol{\eta}_{\text {risk }}$ & Trace & $\begin{array}{c}\text { Cointegration } \\
\text { Max. } \\
\text { eigenvalue }\end{array}$ \\
\hline FY05-Q4 & 0.78 & -0.01 & 0.31 & -0.04 & 1 & 1 \\
& $(6.17)$ & $(-2.17)$ & $(3.14)$ & $(-5.54)$ & & \\
FY06-Q4 & 0.66 & -0.01 & 0.36 & -0.05 & 1 & 1 \\
& $(6.90)$ & $(-2.01)$ & $(3.74)$ & $(-5.75)$ & & \\
FY07-Q4 & 0.68 & -0.01 & 0.34 & -0.04 & 1 & 1 \\
& $(9.03)$ & $(-2.26)$ & $(3.91)$ & $(-6.05)$ & & \\
FY08-Q4 & 0.65 & -0.01 & 0.36 & -0.04 & 1 & 1 \\
& $(9.59)$ & $(-1.98)$ & $(4.51)$ & $(-5.68)$ & & \\
FY09-Q4 & 0.65 & - & 0.47 & -0.03 & 2 & 2 \\
& $(12.97)$ & - & $(8.38)$ & $(-5.20)$ & & \\
FY10-Q4 & 0.84 & -0.02 & 0.26 & -0.05 & 1 & 1 \\
& $(7.18)$ & $(-3.84)$ & $(2.20)$ & $(-4.68)$ & & \\
FY11-Q4 & 1.35 & -0.08 & 0.30 & -0.09 & 1 & 2 \\
& $(6.56)$ & $(-6.64)$ & $(1.41)$ & $(-4.35)$ & & \\
\hline
\end{tabular}




\section{Appendix G}

\section{Bayesian Modeling Results}

\section{Table G1: Benchmark prior estimates}

\begin{tabular}{|c|c|c|c|}
\hline Parameters & Description & $\begin{array}{c}\text { Benchmark } \\
\text { priors }\end{array}$ & Source \\
\hline $\bar{\alpha}$ & $\begin{array}{l}\text { Share of capital in production } \\
\text { function }\end{array}$ & 0.46 & Haider and Khan (2008) \\
\hline$\beta$ & Subjective discount factor & 0.99 & $\begin{array}{l}\text { Ahmed, Haider, and Iqbal } \\
\text { (2012) }\end{array}$ \\
\hline$\rho$ & $\begin{array}{l}\text { Real interest rate in steady } \\
\text { state }\end{array}$ & 0.025 & Authors' calculations \\
\hline$\theta$ & Measure of price stickiness & 0.75 & Haider and Khan (2008) \\
\hline$\kappa$ & Slope coefficient in NKPC & $\frac{(1-\theta)(1-\beta \theta)}{\theta}$ & Haider and Khan (2008) \\
\hline$\gamma$ & Parameter of risk aversion & 0.587 & Ahmed et al. (2012) \\
\hline$\varphi_{1}$ & $\begin{array}{l}\text { Output elasticity of money } \\
\text { demand }\end{array}$ & 0.860 & Authors' calculations \\
\hline$\varphi_{2}$ & $\begin{array}{l}\text { Interest elasticity of money } \\
\text { demand }\end{array}$ & -0.018 & Authors' calculations \\
\hline$\chi_{1}$ & $\begin{array}{l}\text { Sensitivity of central bank } \\
\text { with respect to inflation }\end{array}$ & 1.2 & Authors' calculations \\
\hline$\chi_{2}$ & $\begin{array}{l}\text { Sensitivity of central bank } \\
\text { with respect to output }\end{array}$ & 0.31 & Authors' calculations \\
\hline$\rho_{a}$ & $\begin{array}{l}\text { Persistence of technology } \\
\text { shock }\end{array}$ & 0.97 & Authors' calculations \\
\hline$\rho_{m}$ & $\begin{array}{l}\text { Persistence of money demand } \\
\text { shock }\end{array}$ & 0.47 & Authors' calculations \\
\hline$\rho_{i}$ & $\begin{array}{l}\text { Persistence of monetary } \\
\text { policy shock }\end{array}$ & 0.32 & Authors' calculations \\
\hline
\end{tabular}

Table G2: Model prior and posterior distribution results

\begin{tabular}{lccccccc}
\hline & \multicolumn{3}{c}{ Prior distributions } & \multicolumn{3}{c}{ Posterior distribution } \\
\cline { 2 - 8 } Parameters & Distribution & Mean & SD & Distribution & Mean & $\begin{array}{c}\text { 5th } \\
\text { percentile }\end{array}$ & $\begin{array}{c}\text { 95th } \\
\text { percentile }\end{array}$ \\
\hline$\varphi_{1}$ & gamma & 0.860 & 0.045 & gamma & 0.859 & 0.798 & 0.917 \\
$\varphi_{2}$ & gamma & -0.018 & 0.005 & gamma & -0.024 & -0.026 & -0.009 \\
\hline
\end{tabular}

Note: The posterior means of all the estimation parameters are delivered by 150,000 runs of the Metropolis-Hastings algorithm. We have used MATLAB toolbox Dynare 4.1 for this simulation purpose. 
Figure G1: Bayesian prior vs. posterior distribution plots
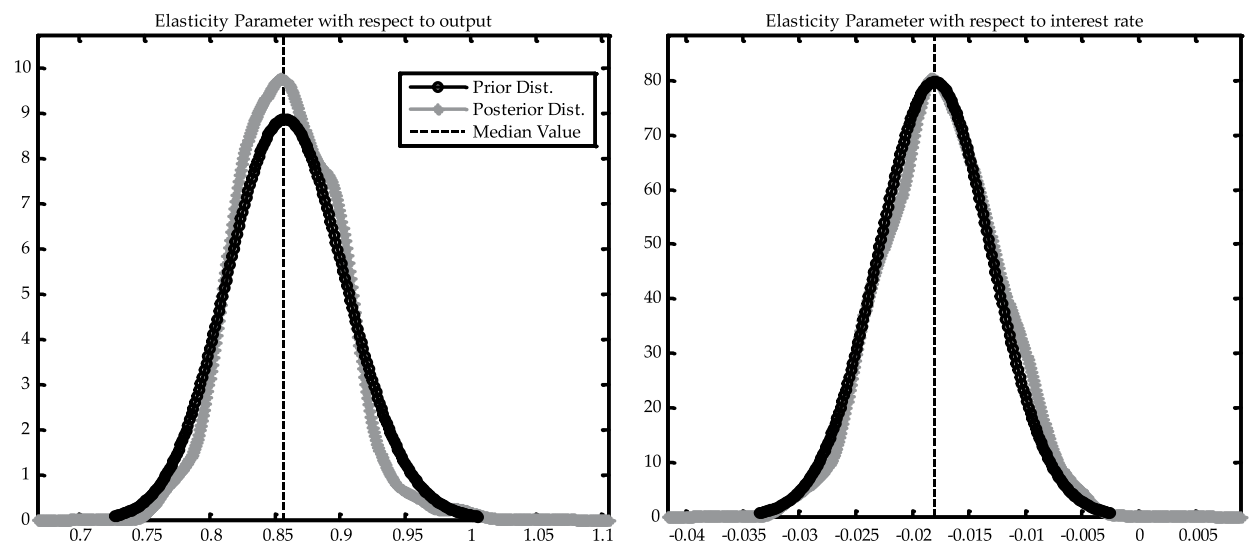

Figure G2: Distribution plots of Bayesian posterior kernel and loglikelihood
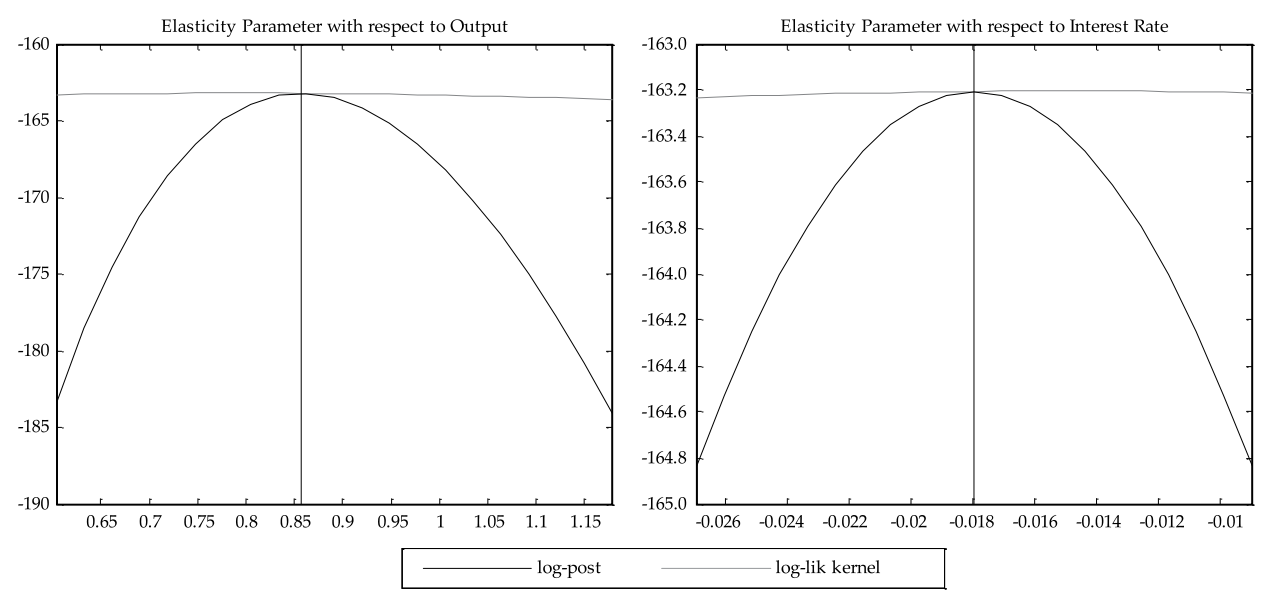


\section{Appendix $\mathrm{H}$}

\section{Stability Results}

\section{Figure H1: Trends in economic activity and first-principal component}
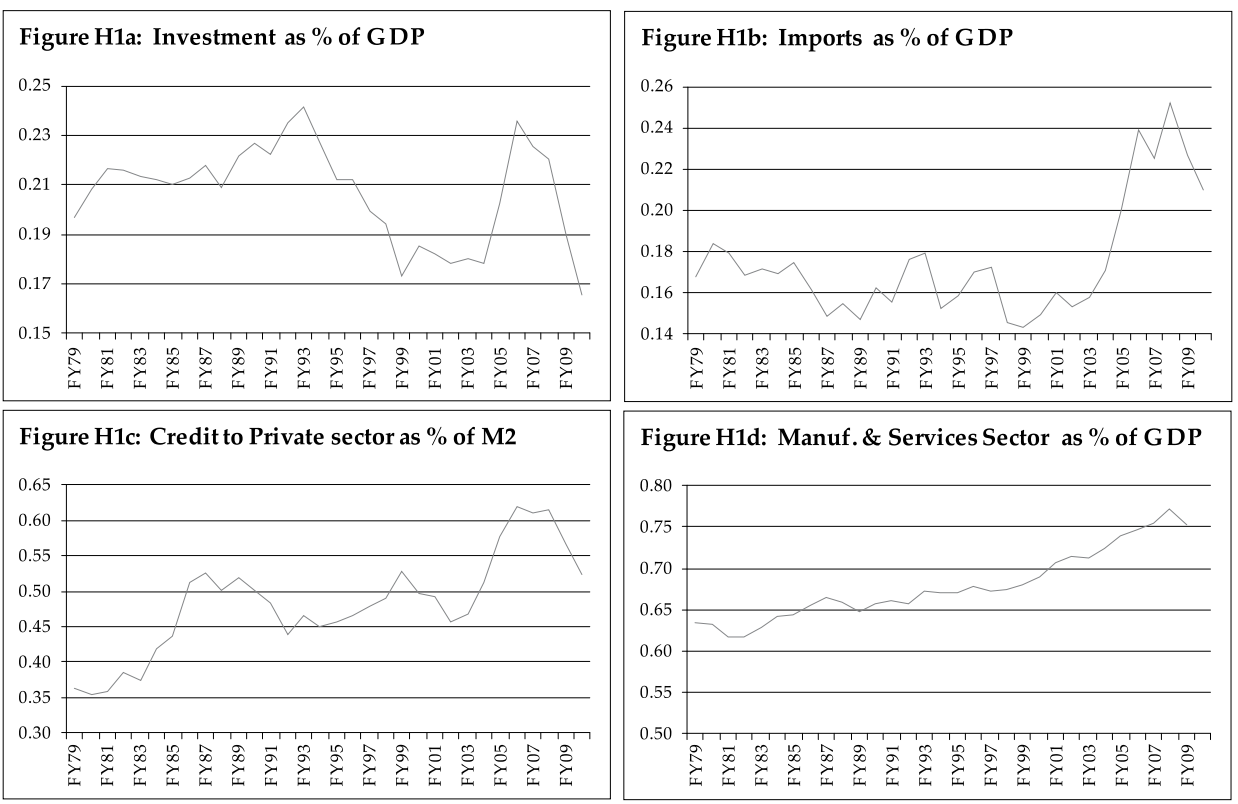

Figure H1d: Manuf. \& Services Sector as \% of GDP

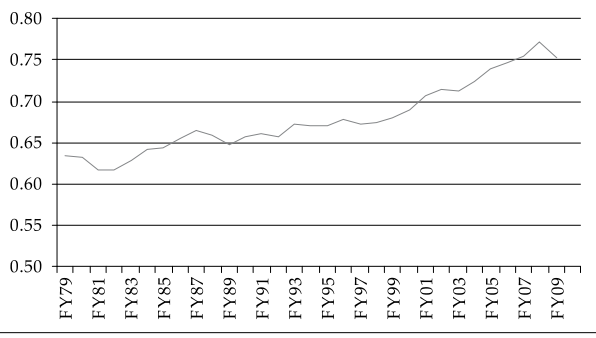

Figure H1e: Government Consumptions as \% of GDP

Figure H1f: First Principle Component of five series
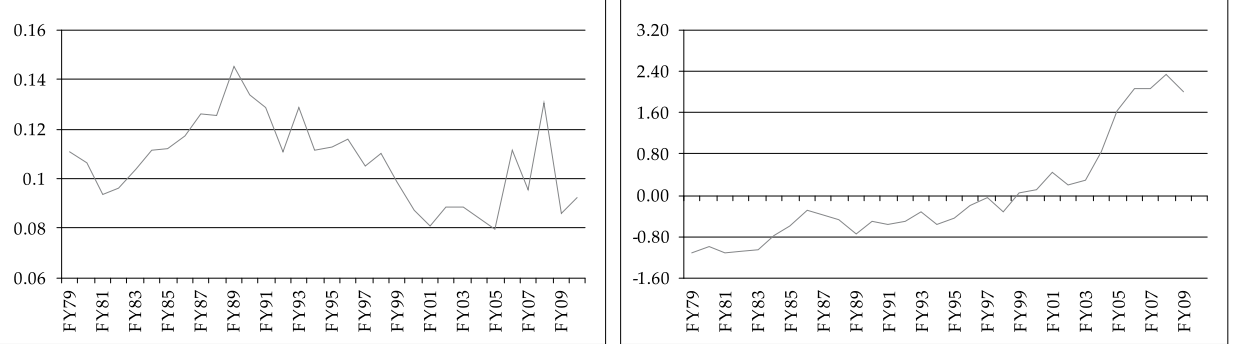
Figure H2: CUSUM and CUMUS square of ARDL Model 4

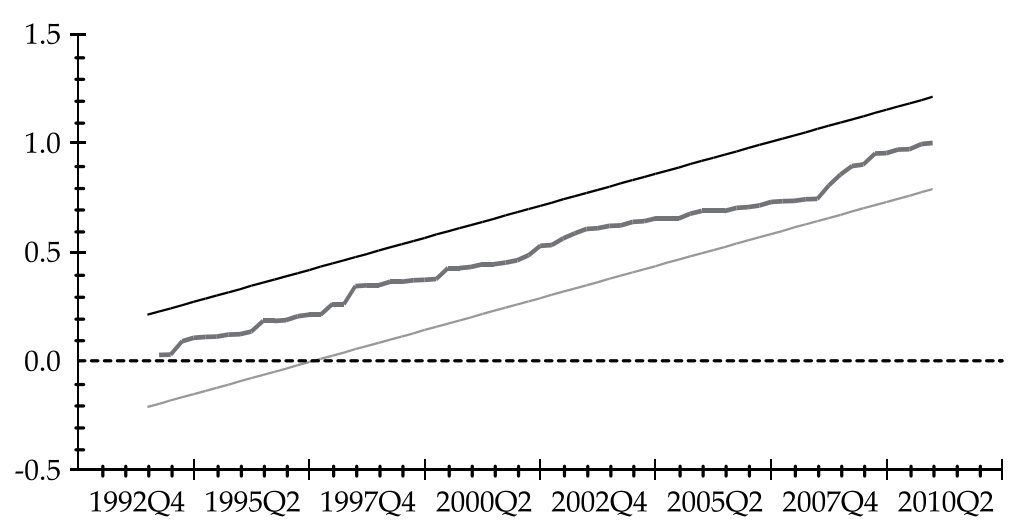

The straight lines represent critical bounds at $5 \%$ significance level

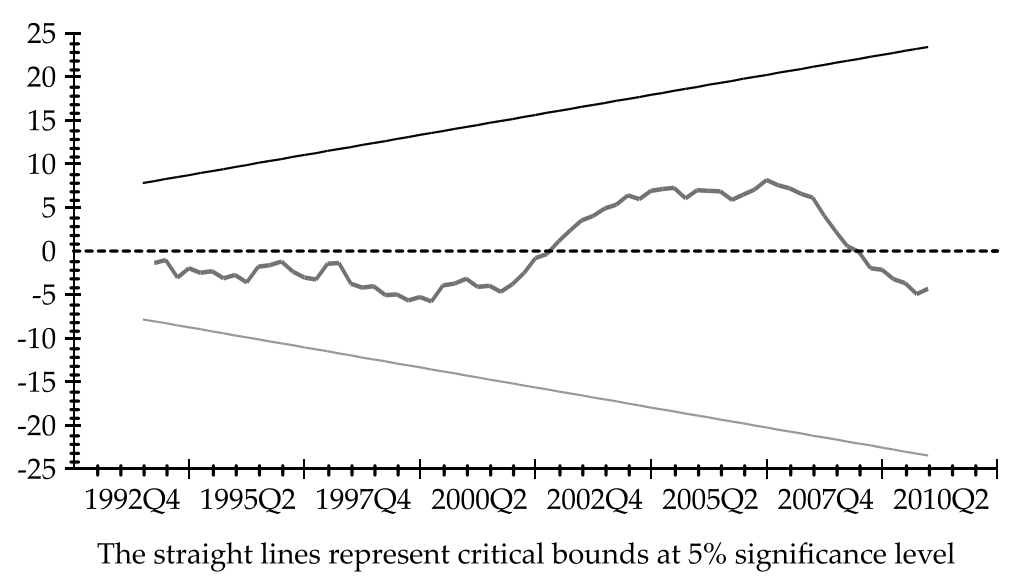


Figure H3: Cointegration relation of Models 2 and 7 (Johansen procedure)

Figure H3a: Cointegration Relation of Model-2

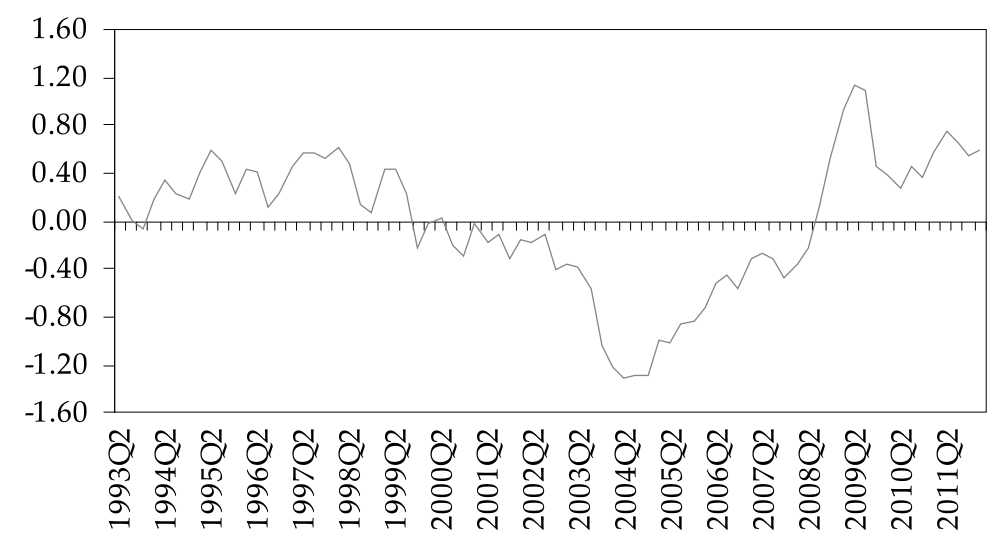

Figure H3b: Cointegration Relation of Model-7

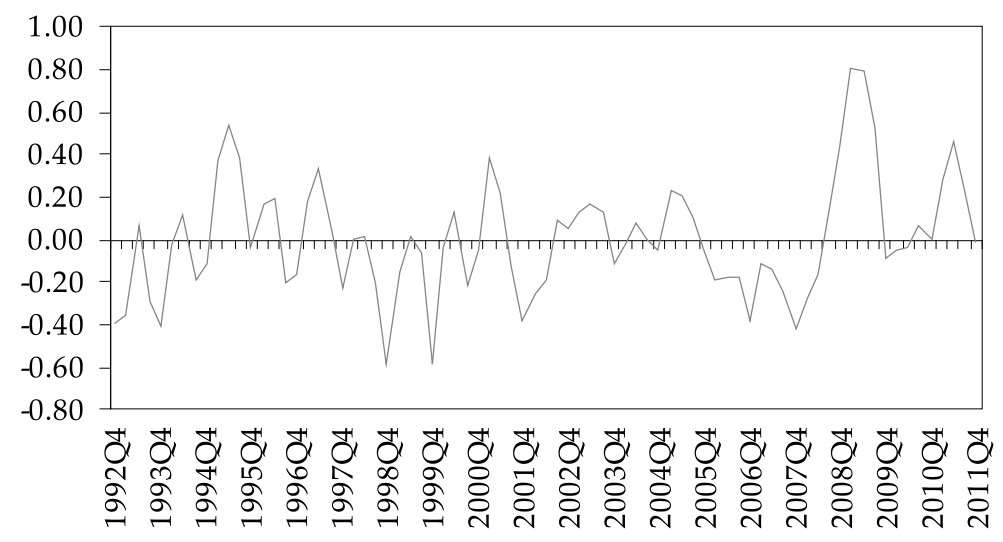


Figure H4: Recursive stability estimates of Model 7 (Johansen procedure)



Figure H5: Bayesian reduced-form screening of parameters

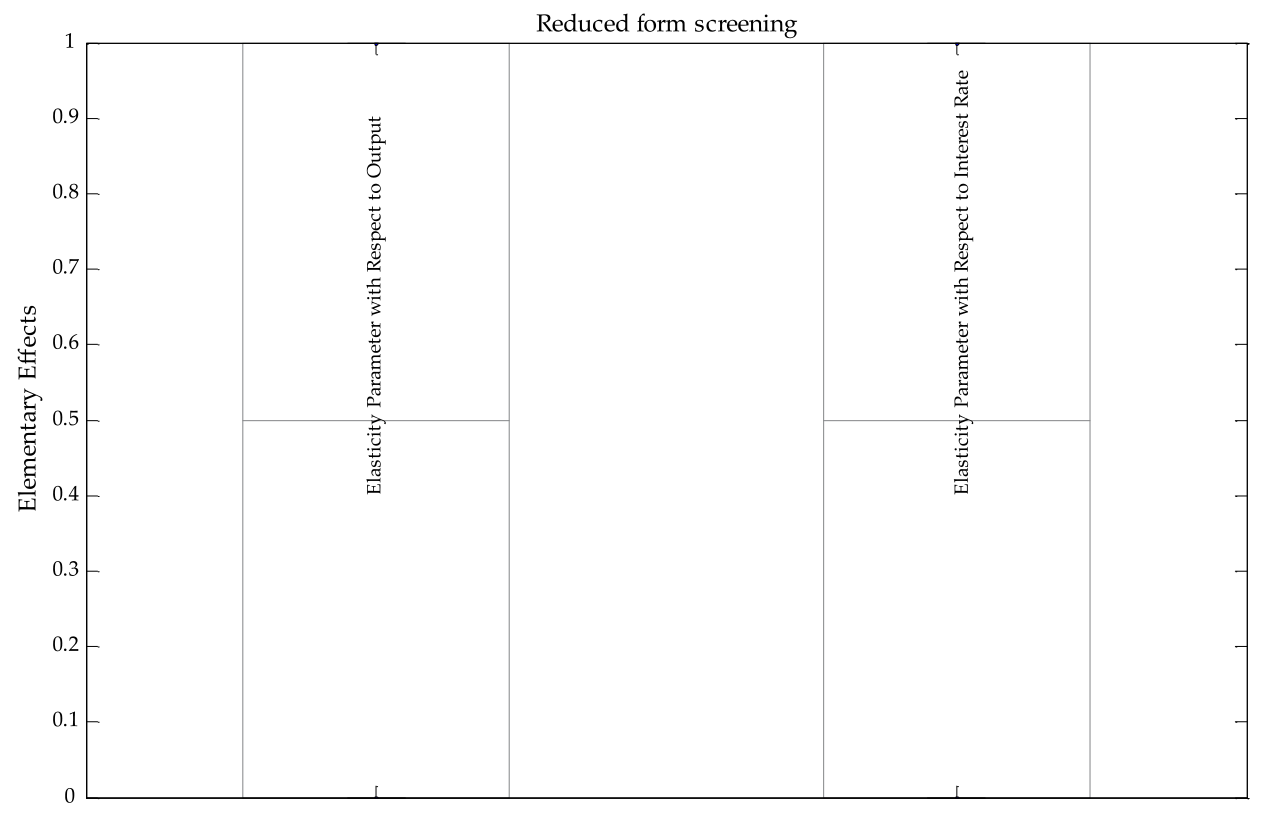


Figure H6: Bayesian posterior stability plots using GSA toolkit
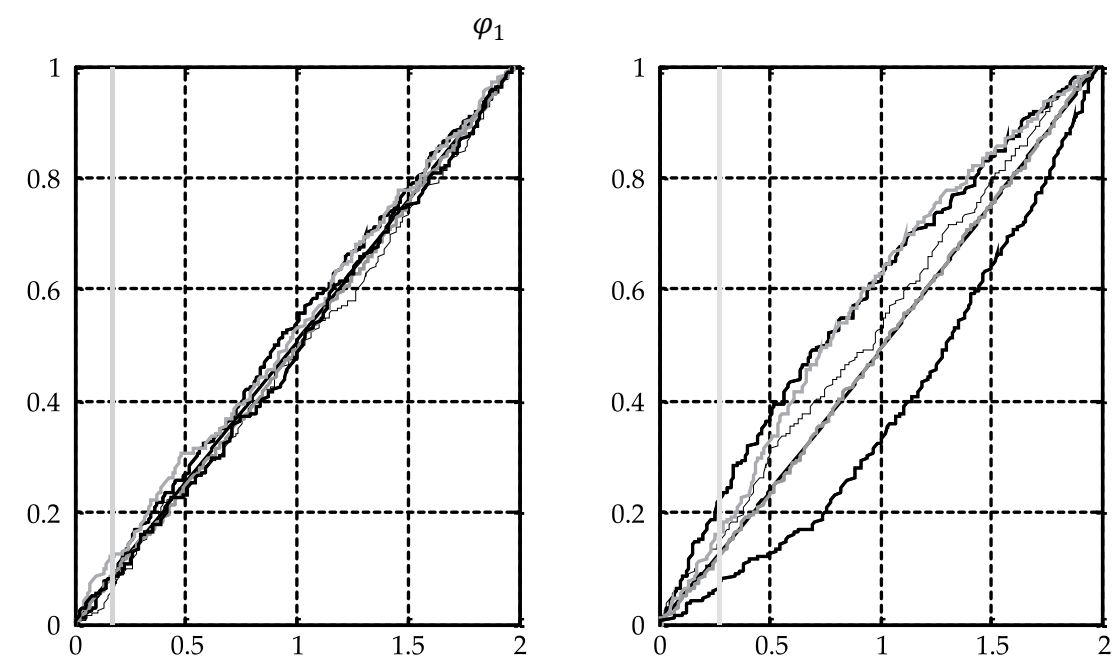

$\varphi_{2}$

Note: Since we have used different specifications of the nominal interest rate, we find different stability paths for the parameters. 


\section{Appendix I}

\section{Selected Empirical Literature Review}

\begin{tabular}{|c|c|c|c|c|}
\hline No. & Study & $\begin{array}{c}\text { Coverage of } \\
\text { variables }\end{array}$ & $\begin{array}{l}\text { Functional } \\
\text { form }\end{array}$ & Findings \\
\hline 1 & $\begin{array}{l}\text { Akhtar (1974) } \\
\text { Sample space: } \\
\text { 1951-70 }\end{array}$ & $\begin{array}{l}\text { M1 } \\
\text { M2 } \\
\text { Interest rates } \\
\text { Real GDP } \\
\text { Inflation }\end{array}$ & Log linear & $\begin{array}{l}\text { Interest rates and income are found } \\
\text { to be the most important } \\
\text { determinants of money demand } \\
\text { function. Long-term interest rates } \\
\text { are significant and robust with unit } \\
\text { elasticity of income. }\end{array}$ \\
\hline 2 & $\begin{array}{l}\text { Abe, Fry, Min, } \\
\text { Vongvipanond, } \\
\text { and Yu (1975) }\end{array}$ & $\begin{array}{l}\text { M1 per capita } \\
\text { M2 per capita } \\
\text { GDP per capita } \\
\text { Interest rates } \\
\text { Inflation }\end{array}$ & Log linear & $\begin{array}{l}\text { Various models for different } \\
\text { definitions of interest rates and } \\
\text { national income. Main determinants } \\
\text { of M1 and M2 are interest rate, } \\
\text { inflation, and income. Interest rate } \\
\text { and inflation rate are statistically } \\
\text { significant with negative sign. } \\
\text { Income is statistically significant } \\
\text { with positive sign. }\end{array}$ \\
\hline 3 & $\begin{array}{l}\text { Khan (1980) } \\
\text { Sample space: } \\
\text { 1960-78 }\end{array}$ & $\begin{array}{l}\text { M1 } \\
\text { M2 } \\
\text { Income (measured) } \\
\text { Income (permanent) } \\
\text { Interest rates } \\
\text { Bank branches }\end{array}$ & Log linear & $\begin{array}{l}\text { Income, rate of interest on time } \\
\text { deposits, inflation, and degree of } \\
\text { monetization are the important } \\
\text { explanatory variables explaining } \\
\text { almost } 99 \text { percent of the variation in } \\
\text { money demand. No evidence for } \\
\text { the hypothesis that permanent } \\
\text { income is a better explanatory } \\
\text { variable than measured income. }\end{array}$ \\
\hline 4 & $\begin{array}{l}\text { Khan (1982) } \\
\text { Sample space: } \\
\text { 1960-78 }\end{array}$ & $\begin{array}{l}\text { M1 } \\
\text { M2 } \\
\text { Income (measured) } \\
\text { Income (permanent) } \\
\text { Interest rates }\end{array}$ & Log linear & $\begin{array}{l}\text { Study conducted for six } \\
\text { developing countries including } \\
\text { Pakistan. Importantly, it does not } \\
\text { alter the main findings of Khan } \\
\text { (1980). However, it finds that } \\
\text { permanent income and expected } \\
\text { inflation are better explanatory } \\
\text { variables in the case of Sri Lanka } \\
\text { compared to measured income and } \\
\text { actual inflation, respectively. }\end{array}$ \\
\hline 5 & $\begin{array}{l}\text { Nisar and Aslam } \\
\text { (1983) } \\
\text { Sample space: } \\
\text { 1960-79 }\end{array}$ & $\begin{array}{l}\text { M1 } \\
\text { M2 } \\
\text { GNP } \\
\text { Interest rates }\end{array}$ & Log linear & $\begin{array}{l}\text { Various models estimated with } \\
\text { alternative measures of interest } \\
\text { rates and money stocks. Main } \\
\text { conclusion is that interest rates are } \\
\text { significant and robust with unit } \\
\text { money elasticity. }\end{array}$ \\
\hline 6 & $\begin{array}{l}\text { Ahmad and } \\
\text { Khan (1990) }\end{array}$ & $\begin{array}{l}\text { M1 } \\
\text { M2 } \\
\text { Real GDP } \\
\text { Interest rate }\end{array}$ & $\begin{array}{l}\text { Log linear } \\
\text { and time- } \\
\text { varying } \\
\text { parametric } \\
\text { approach }\end{array}$ & $\begin{array}{l}\text { Money demand function remains } \\
\text { robust up to } 1980 \text { and unstable } \\
\text { thereafter. }\end{array}$ \\
\hline
\end{tabular}




\begin{tabular}{|c|c|c|c|c|}
\hline No. & Study & $\begin{array}{c}\text { Coverage of } \\
\text { variables }\end{array}$ & $\begin{array}{l}\text { Functional } \\
\text { form }\end{array}$ & Findings \\
\hline 7 & $\begin{array}{l}\text { Hossain (1994) } \\
\text { Sample space: } \\
\text { 1951-91 }\end{array}$ & $\begin{array}{l}\text { M1 } \\
\text { M2 } \\
\text { Real GDP } \\
\text { Yield on govt. bonds } \\
\text { Market call rate } \\
\text { Inflation }\end{array}$ & Log linear & $\begin{array}{l}\text { Stable money demand function } \\
\text { determined through Johansen's } \\
\text { cointegration tests. Interest rate has } \\
\text { a significant negative impact on } \\
\text { money stock with unit elasticity of } \\
\text { income. }\end{array}$ \\
\hline 8 & Qayyum (1998) & $\begin{array}{l}\text { Real money demand } \\
\text { Real income } \\
\text { Yield on long-term } \\
\text { govt. bonds } \\
\text { Measured inflation } \\
\text { Seasonal dummies }\end{array}$ & $\begin{array}{l}\text { Error correction } \\
\text { model }\end{array}$ & $\begin{array}{l}\text { Long-run money-income } \\
\text { proportionality hypothesis is } \\
\text { accepted. }\end{array}$ \\
\hline 9 & Qayyum (2005) & $\begin{array}{l}\text { M2 } \\
\text { Nominal income } \\
\text { Interest rates } \\
\text { Inflation }\end{array}$ & $\begin{array}{l}\text { Johansen's } \\
\text { cointegration } \\
\text { and dynamic } \\
\text { error correction }\end{array}$ & $\begin{array}{l}\text { Inflation is an important } \\
\text { determinant of money demand. } \\
\text { Rates of interest, market rate, and } \\
\text { bond yield are important for long- } \\
\text { run money demand behavior. }\end{array}$ \\
\hline 10 & $\begin{array}{l}\text { Moinuddin } \\
(2009)\end{array}$ & $\begin{array}{l}\text { Real M2 } \\
\text { Real GDP } \\
\text { Real interest rates }\end{array}$ & Log linear & $\begin{array}{l}\text { Money demand function is } \\
\text { unstable in Pakistan and therefore } \\
\text { monetary aggregate targeting is } \\
\text { not suitable. }\end{array}$ \\
\hline 11 & $\begin{array}{l}\text { Omer and Saqib } \\
(2009)\end{array}$ & $\begin{array}{l}\text { M2 } \\
\text { Real GDP } \\
\text { Inflation }\end{array}$ & ARDL & $\begin{array}{l}\text { The quantity theory is an } \\
\text { inadequate explanation of inflation, } \\
\text { income velocity of money is } \\
\text { unstable, and money is endogenous. } \\
\text { These results suggest the need to } \\
\text { rethink monetary targeting strategy } \\
\text { in Pakistan. }\end{array}$ \\
\hline 12 & $\begin{array}{l}\text { Narayan, } \\
\text { Narayan, and } \\
\text { Mishra (2009) }\end{array}$ & $\begin{array}{l}\text { M2 } \\
\text { Yd } \\
\text { ER } \\
\text { Interest rates (foreign } \\
\text { and domestic) }\end{array}$ & $\begin{array}{l}\text { Panel } \\
\text { cointegration } \\
\text { and panel long- } \\
\text { run estimation }\end{array}$ & $\begin{array}{l}\text { Panel Granger causality test } \\
\text { suggests short-run causality } \\
\text { running from all variables, except } \\
\text { foreign interest rate, to money } \\
\text { demand. Money demand functions } \\
\text { are all stable except for Nepal. }\end{array}$ \\
\hline 13 & $\begin{array}{l}\text { Azim et al. (2010) } \\
\text { Sample space: } \\
\text { 1973-2007 }\end{array}$ & $\begin{array}{l}\text { Broad money (M2) } \\
\text { Real GDP } \\
\text { Inflation } \\
\text { Exchange rate }\end{array}$ & ARDL & $\begin{array}{l}\text { Long-run relationship between } \\
\text { broad money and goal variables. } \\
\text { Money demand function is stable } \\
\text { in the case of Pakistan, using } \\
\text { CUSUM and CUSUM square test. }\end{array}$ \\
\hline 14 & $\begin{array}{l}\text { Sample space: } \\
\text { 1975-2006 }\end{array}$ & $\begin{array}{l}\text { Reserve money (M0) } \\
\text { Narrow money (M1) } \\
\text { Broad money (M2) } \\
\text { Velocity of money } \\
\text { (M0, M1, M2) } \\
\text { Call money rate } \\
\text { Nominal GDP } \\
\text { Per capita income } \\
\text { CPI inflation }\end{array}$ & ARDL & $\begin{array}{l}\text { Velocity of base and broad money } \\
\text { is insensitive to interest rate } \\
\text { changes, but responsive to income } \\
\text { and business cycle fluctuations. } \\
\text { However, velocity of narrow } \\
\text { money (M1) depends on interest } \\
\text { rate changes, income, and } \\
\text { business cycle fluctuation. } \\
\text { Money velocities of all three } \\
\text { models are stable using CUSUM } \\
\text { and CUSUM square test. Money } \\
\text { demand is stable. }\end{array}$ \\
\hline
\end{tabular}

